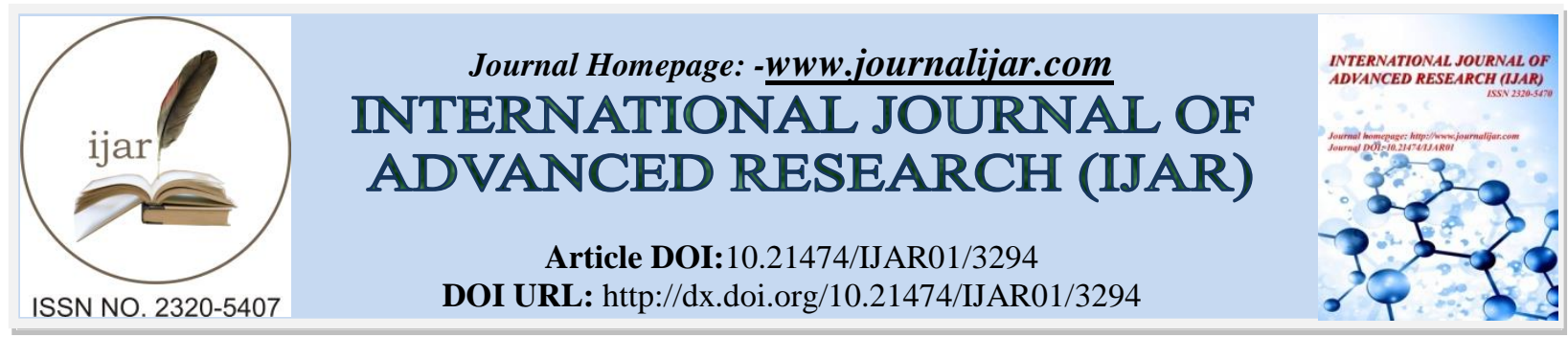

\title{
MONOGENIC DISORDERS: AN OVERVIEW.
}

Usman Babar.

Centre of Agricultural Biochemistry and Biotechnology, University of Agriculture, Faisalabad, Pakistan.

\section{Manuscript Info}

Manuscript History

Received: 20 December 2016

Final Accepted: 25 January 2017

Published: February 2017

\section{Abstract}

Monogenic Disorders (MDs) are the single-gene associated disorders. Approximately 5000 types of these disorders have been known by now. These have been found most commonly in the developing countries, more specifically in the rural areas with the highest ratio due to the consanguineous marriages. The recessive or minor unexpressed disorder carrier gene also gets expressed within their offspring. Depending upon the global prevalence and other various characteristics of the monogenic disorders, these have been classified on the basis of their patterns of inheritance i.e. Autosomal or X-Linked. Likewise, Dominant or Recessive. Several common monogenic disorders have been discussed comprehensively with their etiology, features, effects, diagnosis and cure. Osteogenesis Imperfecta (OGI), Retinoblastoma (RB), Cystic Fibrosis, Thalassemia, Fragile X Syndrome (FXS), Hypophosphatemia, Hemophilia and Ichthyosis are included in the category of MDs and are discussed in detail. Most of the monogenic disorders are rare to happen even their causes are still unknown while some are quite common with known causes. Various diagnostic techniques and the treatment methods have been developed for them which have not been proved enough to treat the disorders by conventional approaches. Therefore, some recent and updated approaches are also being implemented in the field of treatment of these disorders that includes the Gene Therapy, Stem Cell Transplantation and Bone Marrow Transplant.

Copy Right, IJAR, 2017. All rights reserved.

\section{Introduction:-}

Gene is basically a specific length or segment of DNA containing some crucial information for the assembly of amino acids in an order to form a protein. The entire DNA compliment of cell or an organism is known as "Genome" (Alberts, B. et al., 2002; Dongen, J. 2015). It turns on within a cell for a specific time interval only in the case of need. It consists of various alternative forms known as "Alleles" ( Terao, C. et al., 2016), from whom only a single form can be expressed or inherited depending upon its potential of ruling over its partner form in a chromosome (Perry, S. et al., 2014). These alleles or gene may act in an abnormal way and said to be "Mutated" and leads to a "Genetic Disorder" (Bagheri, M. et al., 2015). These genetic disorders can be either Monogenic or Polygenic. Single-Gene or Monogenic Disorders can take place in an organism due to mutation or change in the single gene within a genome (Thornhill, A. et al., 2015). The gene either stops working or perform any unwanted or improper role. While the Polygenic disorders happen due to change or mutation in the multiple genes (Tao, J. et al., 2015).

Corresponding Author: Usman Babar.

Address:- Centre of Agricultural Biochemistry and Biotechnology, University of Agriculture, Faisalabad. Pakistan. 
Monogenic is actually the combination of two Greek words; Mono means "Single" and Genic means "Gene". These are the disorders caused by the inheritance of the single mutated gene from parent to offspring known as "Monogenic disorders or Single-gene Diseases" [MDs] (Tuomi, T. et al., 2014). These disorders are categorized as "Autosomal" or "Sex-Linked" based upon their origin whether the mutation is in an autosome or in a sex chromosome. Further these disorders may exist because of the expression of an allele of a gene over the over i.e. "Dominant" or "Recessive" on the basis of the inheritance of the copy of the single mutated gene either from single parent or both (Kashyap, M. et al., 2015). Whereas, the Monogenic Disorders can also be further categorized as " $X$ Linked", "Y-Linked" and "Mitochondrial" on the inheritance basis of any mutated gene because of mother (Antonarakis \& Beckmann, 2006; Bamshad, M. et al., 2011). These disorders take place due to sex chromosomes. Though there are not much genes in the Y chromosome as it is too small, it does not show any monogenic disorder. Y-Linked disorders are often and polygenic. Most of the monogenic disorders are spontaneous and naturally occurring whereas, some are non-spontaneous and due to environmental changes (Yazdi, F. et al., 2015). There is a large figure of the monogenic disorders i.e. More than 5000 which includes most of the rare disorders along with some of the common ones. Most probably these disorders vary from cell to cell, though the entire genome of the organism is same among all the body cells (Fiorentino, F. et al., 2005; Harper \& Sen Gupta, 2012). The global prevalence of this disease is 10/1000 at the birth and an estimate of 360 Million people are victims of monogenic disorders (Aslamkhan, M. 2015; Irfan-Maqsood, M. 2015).

Monogenic disorders [MDs] have always remained a common issue in the developing countries due to poor environmental factors and unnecessary mutations i.e. Pakistan, India, Afghanistan, Bangladesh and Sri Lanka from Asia. Our main focus is on the health issues regarding to the genetic disorders in Asian sub-continent (Kumar, D. 2012; Yamada, Y. 2006). The percentage of the monogenic disorders is too high in this particular area that includes Thalassemia, Osteogenesis Imperfecta, Hemophilia and Ichthyosis (Pemberton, T. et al., 2012; Ropers, H. 2007). A survey has been conducted recently in 2012, according to which the population of Pakistan is around 190 Million from which more than $65 \%$ of the population belongs to the rural or scattered areas and consanguinity has been observed in almost $80 \%$ of the cases which is one of the most common cause of the inheritance of genetic disorders from generation to generation (Halim, N. et al., 2013; Hussain, R. et al., 2001; Obeidat, B. et al., 2010). As the consanguineous individuals have at least one common ancestor somehow from any of their previous generations. Hence, there are more chances of the occurrence of any genetic disorder whose genes were present among consanguineous parents (Harlap, S. et al., 2008; Sheridan, E. et al., 2013) but were not expressed but now with the inbreeding, risk of disease in the descendant is $99 \%$ sure and can be proved lethal whether the parents are carrier of any dominant defective trait or of recessive, it leads to the congenital disorders and genetic disorders. These disorders affects in both way, genotypic and phenotypic (Bittles, A. 2012; Sandridge, A. et al., 2010; Warsy, A. et al., 2014).

The cause of several monogenic disorders is still unknown; various techniques have been introduced in order to diagnose these disorders at the genetic level over last 3 decades for the better understanding and consideration. As long as the new technologies like Next Generation DNA Sequencing [NGS] and DNA microarrays are being launched (McPherson, E. 2006; Yoo, H. 2010) and getting advanced day by day for the entire Genome [Gene or DNA] Analysis while the prenatal diagnosis has been proved as the conventional one, In contrast to that a number of a number of more monogenic disorders are being identifying (Cavalli, P. 2009; Pagon, R. 2002). Human Genome Project [HGP], a scientific research project, was presented in 2003 that gives the entire information about all the genes present in the human body regarding to their sequence and the functions. Hence, it has been proved very useful for the determination of the causes of disorders that are monogenic as well as polygenic (Antonarakis, S. 2001). In former studies, Mapping techniques have been used so far for the analysis of monogenic disorders. But due to some limitations, Massively Parallel Sequencing [MPS] Technology can also be used for studying the advances relevant to the genome analysis for the determination of monogenic disorders (Duncan, E. et al., 2014).

Monogenic disorders are also known as "Mendelian Disorders" as the concept of inheritance of the genetic characters along with the gene copies was introduced by the Father of Genetics, Gregor Mendel (Kosztolányi, G. 2011; Pembrey, M. 2010; Williams, S. et al., 2014). In order to study about the monogenic disorders inheritance patterns as described by the Mendel's Law, we need to go either through the pedigrees of the characters being mutated within a species or by the help of various molecular techniques such as PCR and Sequencing (Pommerenke, C. et al., 2016) and after the detection of the disorder, the presence of the disorder has been confirmed. Now the struggle towards the remedy of these disorders should be made appropriately (O'Connor \& Crystal, 2006; Wong \& Chiu, 2010). Through the applied and advanced researches we came to know that almost all the monogenic disorders 
are part of the coding regions "Exons" present within the human genome which encodes and controls almost all the body characters as well as functions (Valencia, C. et al., 2015). Hence, our main focus turned towards the exome of the body and the technologies used for the exome analysis are genotypic arrays and the exome sequencing. Just by analyzing the exome rather than the whole genome of an organism (Pommerenke, C. et al., 2016), we may perform experiments and get better results in less time than other sequencing techniques of the entire genome of an organism (Shigemizu, D. et al., 2015). Exome sequencing is basically the selective re-sequencing of a selective segment of the DNA which is doubtful as mutated (Nash, B. et al., 2015). With the help of exome sequencing, while studying a monogenic disorder which have been still unknown by cause and is newly discovered by the sequencing analysis, its certain perspectives get clear with its discovery due to the advancement in the field of genetics and technology (Lacey, S. et al., 2014). But still there is a large figure of the monogenic disorders whose causes are still unknown. It's actually all about the complexity of the disorder which is either at a single site or sequence within a gene at a copy or at the certain sites or sequences within both the copies of gene [Dominant or recessive] (Lalonde, E. et al., 2010; Valencia, C. et al., 2015).

There was no possible cure of monogenic disorders up till now but these days, the advanced remedies are being used and processed further with the passage of time as they are not time consuming at all but these remedies require the experience and are expensive as well as at risk i.e. Stem cell treatment and transformation (Lida, Y. et al., 2014; Xie $\&$ Tang, 2016). These are at risk as the treatment is either on a possibility of being occurring in case transformation for any therapeutic cure or the failure if the vector does not hits the target properly. Whereas, the success rate of stem cell therapy is a bit higher as it is quite efficient that transformation technique and is comprised of the modifications being made in the body cell of patient itself or another healthy donor (O'Connor \& Crystal, 2006).

\section{Modes of Inheritance of Monogenic Disorders:-}

In the Monogenic Disorders, the copy of a mutated gene or multiple copies are inherited and causes a characteristic phenotype of that gene by following the Mendelian Segregation patterns (Ahmed, N. et al., 2006; Chen, N. et al., 2014; Fountain, E. et al., 2016). The patterns of inheritance can be predicted in both cases of autosomes as well as sex chromosomes. They also describe whether the single copy of a gene is inherited and responsible for the cause or the both copies of respective gene are mutated i.e. Dominant and recessive (Lalonde, E. et al., 2010; Valencia, C. et al., 2015). Pedigrees can be drawn to study the family or ancestry record for distinguishing among the affected and wild type generations and individuals in a family line and their pattern of inheritance. [Fig. 1] shows the signs used in the pedigree for distinguish among males and females, affected and wild type (Chen, N. et al., 2014; Fountain, E. et al., 2016).

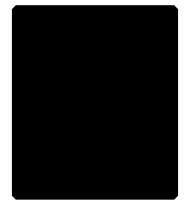

Wild Type Male

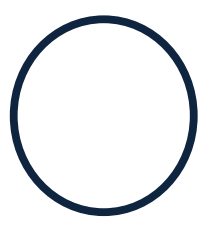

Wild Type Female

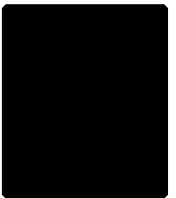

Affected Male

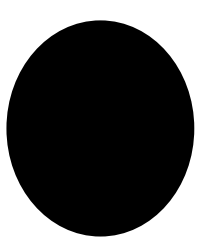

Affected Female

Fig. 1: Signs for Pedigree.

Some crucial modes of inheritance that help in the demonstration of monogenic disorders are as follows [Fig. 2];

1. Autosomal Dominant Inheritance

2. Autosomal Recessive Inheritance

3. X-Linked Dominant Inheritance

4. X-Linked Recessive Inheritance

5. Y-Linked Inheritance 


\section{Modes of Inheritance}

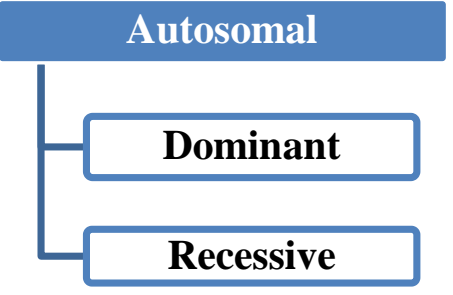

\section{Sex Chromosomal}

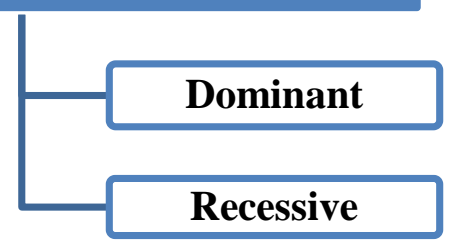

Fig. 2: Modes of Inheritance in Monogenic Disorders.

\section{Autosomal Dominant Inheritance:-}

The monogenic autosomal dominant inheritance takes place due to a single mutated autosomal gene present in any of the parents [Usually Heterozygotes] (Oleinikov, A. 2008; Pan\& Weissman, 2002). As the mutation is on an autosome, hence both the males and females can be equally affected and the probability of the inheritance of the disorder is 50\% due to the presence of a wild type and a mutated allele or gene copy in the child from each of the parents (Regalado, E. et al., 2011). Punnett square helps us in predicting the possible outcomes of the offspring from the single or both affected parents [Table. 1]. A copy of the gene is enough either to produce a wild type or a mutated offspring as the genes are Dominant Autosomal genes are represented as "A" while recessive ones are represented as "a".

Table 1: Possible outcomes of Autosomal Dominant Inheritance

\begin{tabular}{|c|c|c|}
\hline Parents & \multicolumn{2}{|c|}{ Affected Parent } \\
\hline Normal Parent & A & a \\
\hline a & Aa & aa \\
\hline a & Aa & aa \\
\hline Offspring & $\mathbf{5 0 \%}$ Affected & $\mathbf{5 0 \%}$ Normal \\
\hline
\end{tabular}

\section{A: If One Parent is affected}

\begin{tabular}{|c|c|c|}
\hline Parents & \multicolumn{2}{|c|}{ Affected Parent } \\
\hline Affected Parent & A & a \\
\hline A & AA & Aa \\
\hline a & Aa & aa \\
\hline Offspring & $\mathbf{7 5 \%}$ Affected & 25\% Normal \\
\hline
\end{tabular}

\section{B: If Both Parents are affected}

Single dominant in their pattern and one of the parents is surely affected as well. They transmit from generation-togeneration randomly and can remain silent or unexpressed at any generation and again expressed at the other one (Cutting, G. 2010). Pedigree for the autosomal dominant inheritance patterns of the monogenic disorders is shown in [Fig. 3].

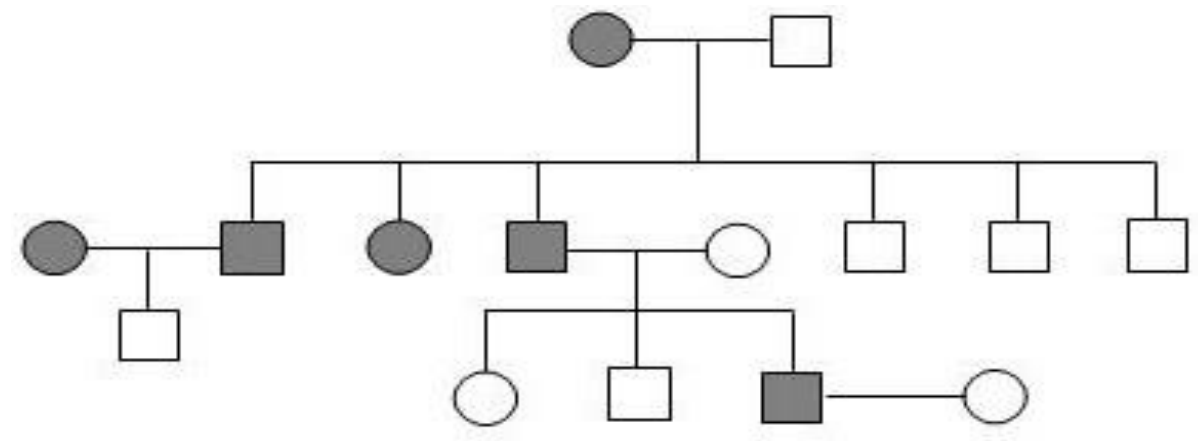

Fig. 3:- Pedigree for the Autosomal Dominant Inheritance. 


\section{Autosomal Recessive Inheritance:-}

In Monogenic autosomal recessive inheritance, the single mutated autosomal gene copy from the both parents is inherited in the offspring [Homozygote] and the repressed or recessive characteristic of a trait is again expressed due to the similar gene copy of both the alleles (Gialluisi, A. et al., 2012; Jonker, M. et al., 2015).

In case of the recessive autosomal inheritance, both the genes present should be mutated. If any of them is wild type than they may be asymptomatic [Doesn't show any of the abnormal features or symptoms] and the individual would be the healthy one phenotypically but are still the carrier of that disease and are capable of passing the disease into the upcoming descendant generations if remain in consanguinity (Harlap, S. et al., 2008; Sheridan, E. et al., 2013). Such disorders can be observed in only single generation as they can be repressed by avoiding the consanguineous relations. The risk of inheritance of these disorders is high in the consanguineous parents. As if both are the carriers of the disorder then there is $25 \%$ possibility of the disorder in the child (Ahmed, N. et al., 2006; Gao, Z. et al., 2015; Henn, B. et al., 2016). Punnett Square helps us in showing the predicting outcomes of the offspring from the normal, affected or carrier parents [Table. 2].

Table 2: Possible Outcomes of Autosomal Recessive.

\begin{tabular}{|c|c|c|}
\hline Parents & Normal Homozygote \\
\hline Normal Heterozygote & A & A \\
\hline A & AA & AA \\
\hline a & Aa & Aa \\
\hline All Normal Offspring & $\mathbf{5 0 \%}$ Homozygous Normal & $\mathbf{5 0 \%}$ Heterozygous Carriers \\
\hline
\end{tabular}

A: If One Parent is Carrier and other is Normal

\begin{tabular}{|c|c|c|}
\hline Parents & \multicolumn{2}{|c|}{ Normal Heterozygous } \\
\hline Normal Heterozygous & A & a \\
\hline A & AA & Aa \\
\hline a & Aa & aa \\
\hline Offspring & $\mathbf{7 5 \%}$ Normal Carriers & Affected Homozygous \\
\hline
\end{tabular}

B: If Both Parents are Carriers

\begin{tabular}{|c|c|c|}
\hline Parents & \multicolumn{2}{|c|}{ Affected Homozygous } \\
\hline Normal Homozygous & $\mathbf{a}$ & $\mathbf{a}$ \\
\hline $\mathbf{A}$ & Aa & Aa \\
\hline $\mathbf{A}$ & Aa & Aa \\
\hline Offspring & \multicolumn{2}{|c|}{$100 \%$ Heterozygous Carriers } \\
\hline
\end{tabular}

\section{C: If one Parent is Affected and Other is Normal}

\begin{tabular}{|c|c|c|}
\hline Parents & \multicolumn{2}{|c|}{ Affected Homozygous } \\
\hline Normal Heterozygous & a & a \\
\hline A & Aa & Aa \\
\hline a & aa & aa \\
\hline Offspring & $50 \%$ Heterozygous Carriers & $\mathbf{5 0 \%}$ Affected Homozygous \\
\hline
\end{tabular}

\section{D: If One Parent is Affected and Other is Carrier}

Pedigree for autosomal recessive inheritance patterns of the monogenic disorders is shown in [Fig. 4].

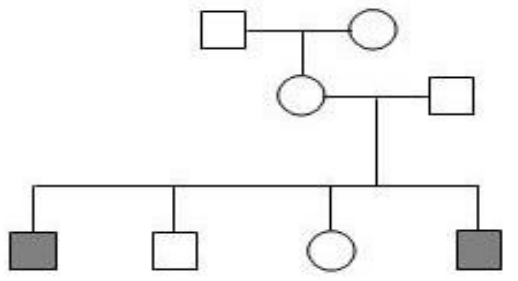

Fig. 4: Pedigree for the Autosomal Recessive Inheritance 


\section{X-Linked Dominant Inheritance:-}

The Mutation in the X-chromosomal gene of the sex chromosomes leads to numerous disorders which are said to be $\mathrm{X}$-Linked Disorders. As the males contain only one $\mathrm{X}$ while the females contains $2 \mathrm{X}$-Chromosomes (Dobyns, W. 2006). Hence, the pattern of inheritance of the $X$-Linked dominant disorders is straight forward it will either produce the affected offspring or the normal ones at the possibility of 50\% and the disorder transmits continually over the generations because the mutated gene is Dominant and it has to be expressed at each condition (Dobyns, W. et al., 2004; Rappaport, H. 2003).

The sons of affected father will not be affected further nor inherit the disorder whereas, the daughters would surely be the carriers or the affected ones and keep on inherit the disorder (Amberger, J. et al., 2015; Chong, J. et al., 2015).

Punnett Square helps us in showing the predicting outcomes of the offspring from the Normal and Affected parents [Table. 3]. Normal Chromosome is represented as " $\mathbf{X}$ " while the affected one is represented as " $\mathbf{X}$ ".

Table 3: Possible Outcomes for X-Linked Dominant Inheritance

\begin{tabular}{|c|c|c|}
\hline Parents & \multicolumn{2}{|c|}{ Affected Female } \\
\hline Normal Male & $\mathbf{X}, \mathbf{X}$ \\
\hline $\mathbf{X}$ & $\mathbf{X}^{\prime} \mathbf{X}$ & $\mathbf{X X}$ \\
\hline Y & $\mathbf{X}^{\prime} \mathbf{Y}$ & $\mathbf{X Y}$ \\
\hline Offspring & $\mathbf{5 0 \%}$ Affected & $\mathbf{5 0 \%}$ Normal \\
\hline
\end{tabular}

A: If Mother is Affected and Father is Normal

\begin{tabular}{|c|c|c|}
\hline Parents & \multicolumn{2}{|c|}{ Normal Female } \\
\hline Affected Male & X & X \\
\hline X' & X'X & X'X \\
\hline Y & XY & XY \\
\hline Offspring & $\mathbf{5 0 \%}$ Affected Females & $\mathbf{5 0 \%}$ Normal Males \\
\hline
\end{tabular}

\section{B: If Mother is Normal and Father is Affected}

Pedigree for the inheritance patterns of X-Linked Dominant monogenic disorders is shown in [Fig. 5].

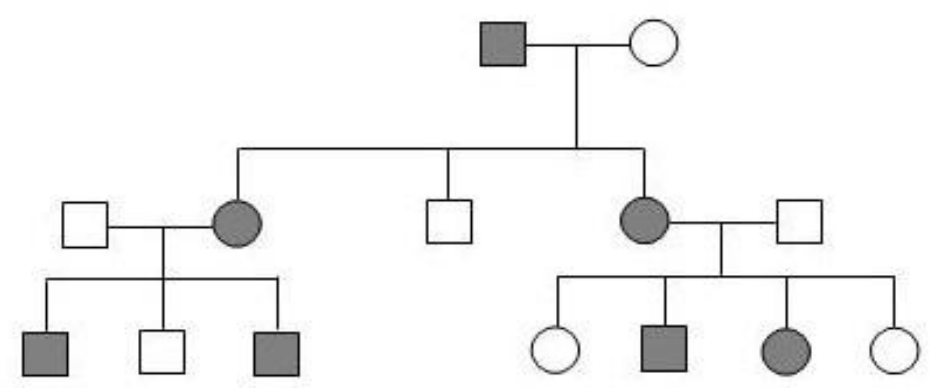

Fig. 5: Pedigree for X-Linked Dominant Inheritance.

\section{X-Linked Recessive Inheritance:-}

The X-Chromosomal genes are mutated in the X-Linked recessive monogenic disorders which are not expressed as a characteristic trait under certain conditions of the heterozygote but can only be expressed in case of the homozygote or hemizygote [Gene with one allele at a loci instead of two] (Bamshad, M. et al., 2011). In X-linked recessive disorder, the hemizygotes are mostly the male ones as they consists of two different genes at different loci and are commonly affected as comparative to the female ones (Rappaport, H. 2003).

Though the females have an affected chromosome but there is an unaffected chromosome present as well and due to Lyonization process (Boulard, M. et al., 2016), only one chromosome is functional or active at a time. Hence, the female would be carrier of disease and is unaffected itself but have the ability to pass the disorder over the 
generations in the offspring (Amberger, J. et al., 2015; Chong, J. et al., 2015). Punnett Square helps in showing the possible outcomes of the offspring from Affected, Normal and Carrier Parents [Table. 4].

Table 4: Possible Outcomes for X-Linked Recessive Inheritance.

\begin{tabular}{|c|c|c|}
\hline Parents & \multicolumn{2}{|c|}{ Normal Female } \\
\hline Affected Male & $\mathbf{X}$ & $\mathbf{X}$ \\
\hline $\mathbf{X}$ & $\mathbf{X} \mathbf{X}$ & $\mathbf{X} \mathbf{X}$ \\
\hline Y & XY & XY \\
\hline Offspring & $\mathbf{5 0 \%}$ Carrier Females & $\mathbf{5 0 \%}$ Normal Males \\
\hline
\end{tabular}

\begin{tabular}{|c|c|c|}
\hline A: If Mother is Normal and Father is Affected \\
\hline Parents & X & Carrier Female \\
\hline Normal Male & XX & X' \\
\hline$X$ & XY & X'X \\
\hline Y & $25 \%$ Carrier Females \\
\hline Offspring & $25 \%$ Normal Females & $25 \%$ Normal Males \\
& & $25 \%$ Affected Males \\
\hline
\end{tabular}

\section{B: If Mother is Carrier and Father is Normal}

\begin{tabular}{|c|c|c|}
\hline Parents & \multicolumn{2}{|c|}{ Carrier Female } \\
\hline Affected Male & $\mathbf{X}$ & $\mathbf{X}^{\prime}$ \\
\hline $\mathrm{X}^{\prime}$ & $\mathbf{X}^{\prime} \mathbf{X}$ & $\mathbf{X}^{\prime} \mathbf{X}^{\prime}$ \\
\hline $\mathbf{Y}$ & XY & $\mathbf{X}^{\prime} \mathbf{Y}$ \\
\hline Offspring & $\begin{array}{l}\text { 25\% Affected Females } \\
\text { 25\% Carrier Females }\end{array}$ & $\begin{array}{l}\text { 25\% Affected Males } \\
\text { 25\% Normal Males }\end{array}$ \\
\hline
\end{tabular}

\section{C: If Mother is Carrier and Father is Affected}

Pedigree for the X-Linked Recessive Inheritance Patterns of the Monogenic Disorders is shown in [Fig. 6].

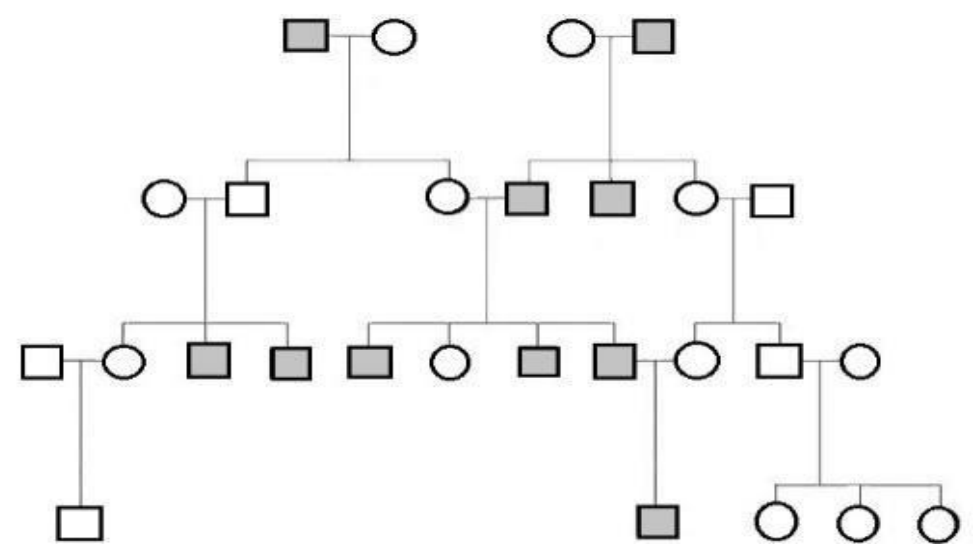

Fig. 6: Pedigree for X-Linked Recessive Inheritance

\section{Y-Linked Inheritance:-}

The gene on the Y-Chromosome is mutated which leads to the Y-Linked Genetic disorders. As the Y-Chromosome is much smaller in size and comprised of a few genes. Hence, there are very limited Y-Linked genetic disorders which are too rare as well (Amberger, J. et al., 2015), which mainly cause the fertility problems and are not usually inherited to the offspring but in some of the cases may be inherited but just affects the sons whereas, the daughters are entirely healthy as they does not carry any Y-Chromosome. Hence, it can be easily distinguished (Hadi, S. 2015). Pedigree for the Y-Linked Inheritance Patterns of the Monogenic Disorders is shown in [Fig. 7]. 


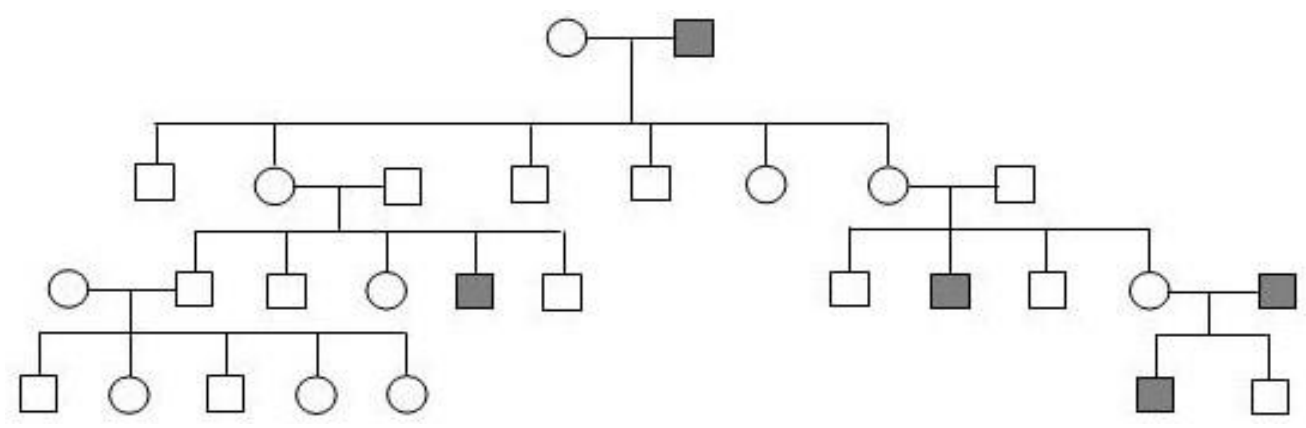

Fig. 7: Pedigree for Y-Linked Inheritance

\section{Frequency of Occurrence:-}

As Mentioned above, the differences among the modes of inheritance of the monogenic disorders are described in detail but their possibility of occurrence over their patterns of inheritance within the offspring of the normal, affected or the carrier parents (Ahmed, N. et al., 2006; Chen, N. et al., 2014; Fountain, E. D. et al., 2016) is described as below in [Table. 5]. The major frequencies of occurrence of the monogenic disorders distinguishing among autosomes and sex chromosomes are as follows;

Table 5: Frequency of Occurrence

\begin{tabular}{|l|c|c|c|}
\hline & Autosomal Dominant & Autosomal Recessive & X-Linked \\
\hline No. of Mutations in Patients & 1 & 2 & 1 \\
\hline Sex of Patients & Both & Both & Usually Boys \\
\hline Risk of Affected Offspring & 1 on 2 & Small & Small \\
\hline Risk of Affected Grandchild & 1 on 4 & Small & 1 on 8 \\
\hline Risk of an Affected Sibling & $\begin{array}{c}\text { Small, if parents are } \\
\text { Normal }\end{array}$ & 1 on 4 & Small, If mother isn"t \\
& Carrier \\
& 1 on 2, If any & & $\begin{array}{c}\text { on 4, if Mother is } \\
\text { Carrier }\end{array}$ \\
\hline
\end{tabular}

\section{Classification of Monogenic Disorders:-}

The monogenic disorders [MDs] are very much in number therefore, they are classified into several categories on the cellular, organ and system basis whose origin is either case is actually a mutated gene. Some of the most common monogenic disorders (Antonarakis \& Beckmann, 2006; Bamshad, M. et al., 2011) are mentioned in the [Table. 6] and all the perspectives of these disorders are discussed in detail, in this review article.

Table 6: Classification of Some Monogenic Disorders in Different Organs

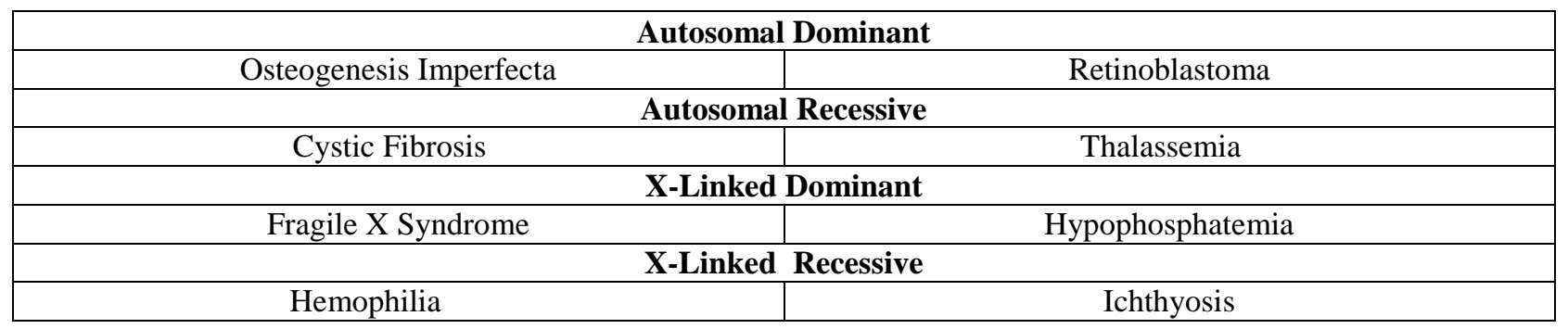

\section{Autosomal Dominant Monogenic Disorders:- Skeleton: Osteogenesis Imperfecta:-}

Osteogenesis Imperfecta [OGI] is a congenital and heritable genetic disorder of abnormal bone or skeletal tissues formation which is either low in mass or weak enough to be fracture. The ratio of the disease at global incidence is about 1 per 10,000 of the individuals (Primorac, D. et al., 2001; Wekre, L. et al., 2011). Some ancient names were given to this disease (Chevrel, G. 2004; Madu \& Olamijulo, 2013) are as follows; 


\section{$>$ Brittle Bone Disease \\ $>$ Glass Bone Disease \\ $>$ Lobstein's Disease \\ $>$ Porak \& Durante's Disease}

\section{Etiology:-}

OGI takes place due to the mutation in any of the collagen type-I encoding genes which is most of the whole body protein content among the connective tissues i.e. COL1A1 and COL1A2 genes (Byers, P. et al., 2006; Christian, C. et al., 2015). Serum albumin or Vitamin D deficiency is not related to OGI, this helps in distinguishing OGI from Osteomalacia (Chagas, C. et al., 2012). As in most of the skeletal disorders, these are the major causes but OGI is a congenital disorder which occurs due to autosomal dominant transmission (Shapiro, J. et al., 2013). The cytogenetic location of the Osteogenesis Imperfecta causing COL1A1 or COL1A2 gene is 7q21.3 (Marini, J. et al., 2014).

\section{Classification of OGI:-}

The classification of OGI was presented by Sillence in 1976 on the severity of the disease basis that is categorized into four major types whereas; the latter ones are the sub-types of Type-IV OGI, as they are correlated. Some clinical features of all the types of OGI are represented in [Table. 7] which helps in distinguishing among them while the examination of disease (Marini, J. et al., 2014; Roughley, P. et al., 2003).

Table 7: Classification of Osteogenesis Imperfecta \& its Clinical Features

\begin{tabular}{|c|c|c|c|c|c|}
\hline \multicolumn{6}{|c|}{ Clinical Features of OGI } \\
\hline Types & Characteristic & Deformity & Symptoms & Phenotype & References \\
\hline I & Bone Fragility & No & Blue Sclera & Normal & \multirow{4}{*}{$\begin{array}{l}\text { (P. J. Roughley et al., } \\
\text { 2003) }\end{array}$} \\
\hline II & $\begin{array}{l}\text { Lethal Perinatal } \\
\text { Period }\end{array}$ & Severe & $\begin{array}{l}\text { Undeveloped lungs \& } \\
\text { fractured ribs }\end{array}$ & Variable & \\
\hline III & $\begin{array}{l}\text { Dentinogenesis } \\
\text { Imperfecta }\end{array}$ & Severe & $\begin{array}{l}\text { White Sclera \& short } \\
\text { stature }\end{array}$ & Very Short & \\
\hline IV & Fractures at birth & Moderate & $\begin{array}{l}\text { Skeletal deformity \& } \\
\text { short stature }\end{array}$ & Variable & \\
\hline $\mathbf{V}$ & $\begin{array}{l}\text { Mesh-like } \\
\text { appearance }\end{array}$ & Moderate & $\begin{array}{l}\text { Hypeplastic callus \& } \\
\text { Interosseous membrane }\end{array}$ & Variable & $\begin{array}{l}\text { (F. H. Glorieux et al., } \\
2000)\end{array}$ \\
\hline VI & $\begin{array}{l}\text { Fish-Scale like } \\
\text { Lamella appearance }\end{array}$ & $\begin{array}{l}\text { Moderate to } \\
\text { Severe }\end{array}$ & $\begin{array}{l}\text { Osteoid } \\
\text { Accumulation \& } \\
\text { abnormal lamellation }\end{array}$ & Variable & $\begin{array}{l}\text { (F. H. Glorieux et al., } \\
\text { 2002) }\end{array}$ \\
\hline VII & $\begin{array}{l}\text { Due to autosomal } \\
\text { recessive pattern }\end{array}$ & $\begin{array}{l}\text { Moderate to } \\
\text { Severe }\end{array}$ & Short humerus/femur & Variable & $\begin{array}{l}\text { (L. M. Ward et al., } \\
\text { 2002) }\end{array}$ \\
\hline
\end{tabular}

\section{Diagnosis:-}

OGI cannot be diagnosed at birth but at the age of walking or adulthood. The genetic analysis of the collagen type-I encoding genes has to be made at the first by keeping the clinical features of the disorder in sight (Marini, J. et al., 2014). Among all the clinical features, Scoliosis is the most common one which leads directly to the death due to the respiratory disorders (Dogba, M. et al., 2016; Dogba, M. et al., 2014).

Differential diagnosis of the disorder should also be made for avoiding the confusion of the similar symptoms of different diseases like, OGI is due to genetic mutation while other disorders might be due to vitamin D or calcium deficiency (Chagas, C. et al., 2012). Some skeletal disorders which resemble OGI may take place while performing the differential diagnosis i.e. Hypophosphatasia, Bruck Syndrome and Cole-Carpenter Syndrome (Henderson, B. et al., 2016). Bone biopsy in some cases may also show some abnormalities that help in the diagnosis (Cheung, M. et al., 2007; Glorieux, F. et al., 2000; Rauch, F. et al., 2013; Zeitlin, L. et al., 2006). 


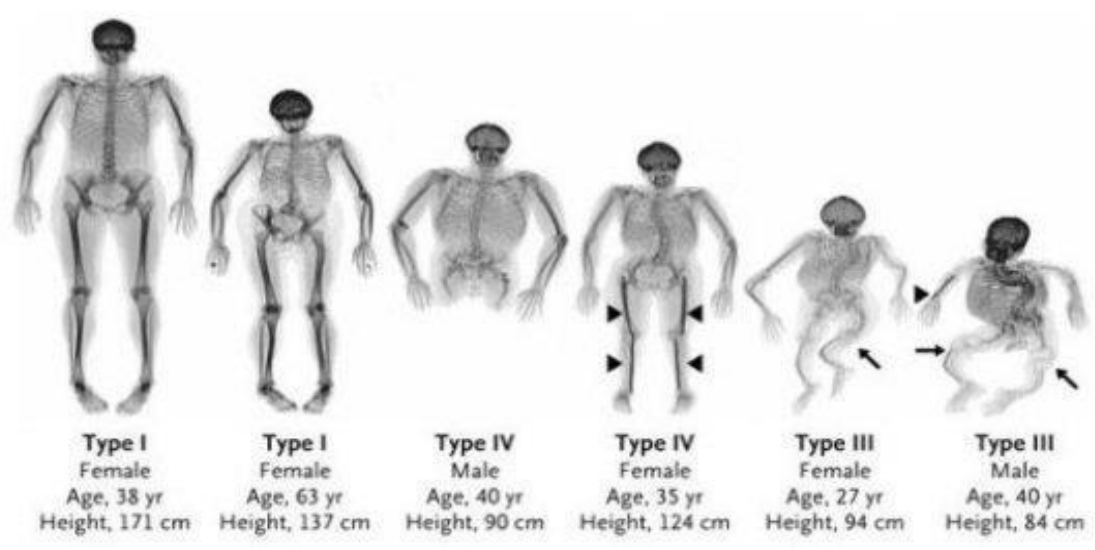

Fig. 8: Classification of Osteogenesis Imperfecta

\section{Treatment:-}

OGI can be treated by the help of medications or orthopedics in order to reduce the fracture rates and prevention from deformities. Medications involve Bisphosphonates, Neridronate and Estrogen (Alharbi, S. 2016) whereas; some therapeutic treatments of the disease are also available.

\section{Pamidronate Therapy:-}

It is a medical technique that is used to get relief from pain and provides enhancement in Bone Mineral Density [BMD] and vertebrae size. In contrast to this, it also favors the decrease in fracture incidence (Plotkin, H. et al., 2000; Van Dijk \& Sillence, 2014).

\section{Gene Therapy:-}

It is another approach for the OGI treatment by which the mesenchymal stem cells of the OGI patients can be taken, modified or transformed in vitro and reinjected into the patient. This technique prevents the expression of mutant genes (Lindahl, K. et al., 2014; O’Sullivan, E. et al., 2014).

\section{Stem Cell Transplantation:-}

Bone marrow or its cells can be transplanted into the patient by taking up from a healthy donor in order to overcome the disease. This method provides best results even in the low concentrations and is the most recent one (Li, F. et al., 2010; Pauley, P. et al., 2014).

\section{Sight: Retinoblastoma:-}

Retinoblastoma is also a congenital disorder that is one of the most common intraocular tumors of the eye retina (Lakhoo \& Sowerbutts, 2010; Shields \& Shields, 2004). It is actually a rare disease. Its global incidence is about 1 in 17000 to $24000.60 \%$ of the cases are observed to be occurred by the age of four years while remaining $40 \%$ of the cases occur at the early developmental stage in infants [Infancy] (Bakhshi \& Bakhshi, 2007; Meel, R. et al., 2012).

\section{Etiology:-}

Retinoblastoma may be hereditary and sometimes non-hereditary as it happens due to the mutation in RB1 gene. The loss of any of RB1 alleles leads to the retinal cancer while, the loss of other allele would cause the development of the tumor within an individual (Barello,S. et al., 2016; Dimaras, H. et al., 2012; Luo \& Deng, 2013; Selistre, S. et al., 2016). RB1 gene is a cell cycle negative regulator gene that has ability to repress the transcription and it is the first gene that have been cloned as tumor suppressor (Hanahan \& Weinberg, 2011). The mode of disease transmission is autosomal dominant if inherited; one of the parents must also be affected to the presence of that dominant trait (Bakhshi \& Bakhshi, 2007). The cytogenetic location of the Retinoblastoma causing gene is 13q14.2.

\section{Classification:-}

Retinoblastoma has been generally classified into 3 different categories; 
1. Familial or sporadic

2. Bilateral or unilateral and

3. Heritable or non-heritable (Ghassemi, F. et al., 2014).

Former two categories are usually used for the clinical diagnosis. Therefore, the cases could be in the format of the combination of both the former categories i.e. unilateral sporadic, bilateral sporadic, unilateral familial or bilateral familial (Abramson, D. et al., 2003; Bartuma, K. et al., 2014). Approximately $2 / 3^{\text {rd }}$ of these cases are unilateral while the $1 / 3^{\text {rd }}$ of them are bilateral. The study of Retinoblastoma gets much easier with the latter one classified category i.e. Heritable or Non-Heritable (MacCarthy, A. et al., 2013; Mendoza \& Grossniklaus, 2015). All of these categories are correlated. Bilateral and familial retinoblastoma has been found to be caused via germ-line mutation; therefore, it is a heritable cancer or tumor (Mohd Khalid, M. et al., 2015). In contrast to this, unilateral and sporadic retinoblastomas aren't heritable at all. Whereas, scarcely $10-15 \%$ of the cases has been detected having unilateral sporadic retinoblastoma via germ-line mutation. DNA testing of the suspected child helps in the identification of the cause whether it is heritable or not (Lakhoo \& Sowerbutts, 2010; Shields \& Shields, 2004).

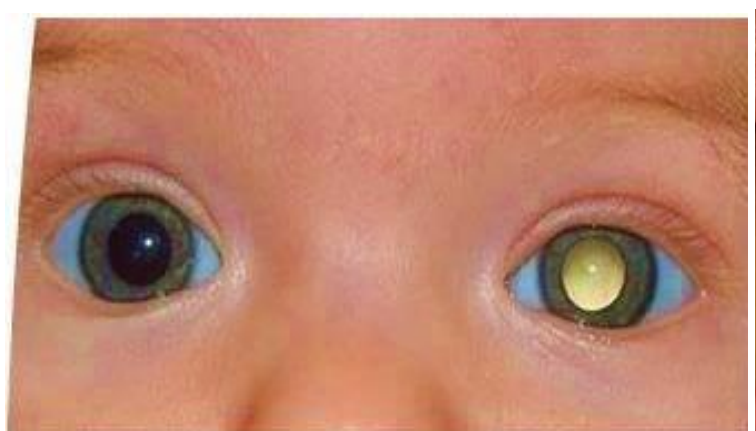

Unilateral Sporadic

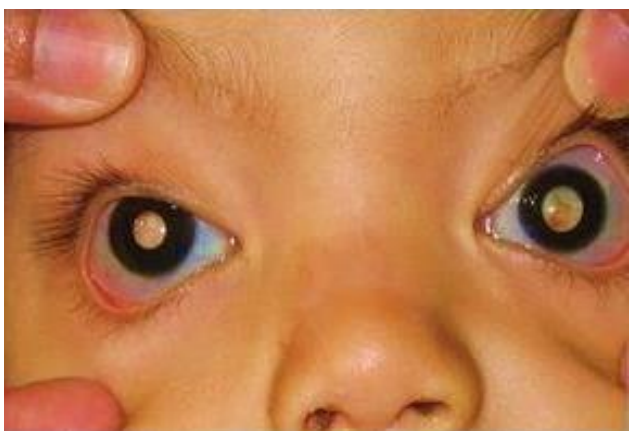

Bilateral Familial

Fig. 9: Classification of Retinoblastoma

\section{Genetic Advancement of Retinoblastoma:-}

As the major cause of the disease is the absence of the RB1 gene which turns the retinal cells into malignant and leads to 'Retinoma' that is the precursor of Retinoblastoma. Retinoma has been found occasionally in $5 \%$ of the individuals (Dimaras, H. et al., 2008; Rushlow, D. et al., 2013). On the other hand, it has also been detected in 16\% of the enucleated cause. Non-dividable retinoma represents the RB1 gene loss along with the low genetic instability i.e. an additional allele on 1q chromosome contains a motor protein KIF14 and an apoptotic regulator MDM4. Dividable retinoma represents high genetic instability (Bowles, E. et al., 2007; Thériault, B. et al., 2014) having extra oncogene copies KIF14, DEK, E2F3 and MYCN with the loss of CDH11, a tumor suppressor gene (Marchong, M. et al., 2010).

As, all the tumors are linked with the body cell changes and requires the entire genome sequencing for the identification of the changes or mutations which are responsible for the cause of malignancy. These oncogenes have the tendency to enhance tumor growth, aggressiveness, resistance to therapy and metastasis (Hudson, T. et al., 2010)

Table 8: Risk of occurrence of Retinoblastoma in siblings \& offspring of affected individuals

\begin{tabular}{|l|c|}
\hline Subjects & Probability of Disease \% \\
\hline RB1 gene mutation carriers & 90 \\
\hline Offspring of Affected individual & 45 \\
\hline Sibling of Affected individual (if either parent is affected) & 45 \\
\hline Sibling of Affected individual with bilateral disease & 2 \\
\hline Sibling of Affected individual with unilateral disease & 1 \\
\hline
\end{tabular}

\section{Diagnosis:-}

Entire history, physical examination, external ocular inspection, slit lamp bio-microscopy and indirect ophthalmoscopy with scleral indentation are usually required for the precise diagnosis of a suspected child having retinoblastoma. The site of all the tumors and their number would be determined while going specifically towards the retinal tumors (Shields, C. et al., 2015). Biopsy is rarely required in such cases. Some additional diagnostic 
studies have been proved quite beneficial for the confirmation of the retinoblastoma. Fluorescein angiography, Ultrasonography and computed tomography help in the demonstration of intraocular tumors along and also detect the calcium content in the mass (Lakhoo \& Sowerbutts, 2010; Shields \& Shields, 2004).

About 5-10\% retinoblastomas don't represent any intrinsic calcification. There are numerous diseases that resemble the retinoblastoma in infants (Shields, C. et al., 2013). In about 50\% of the cases patients shows the symptoms of retinoblastoma at initial stage but latter it doesn't seems to be retinoblastoma due to its simulating conditions. Pseudo-retinoblastomas are actually the most common that involves persistent hyperplastic primary vitreous, ocular toxocariasis and coats disease (Shields \& Shields, 2004). Such confusions can be overcome by the differential diagnosis. Hence, the confirmation of the tumor located is necessary to be diagnosed prior to the treatment. Genomic analyses and microarray expression studies are the convenient techniques for the detection of the disease (Thériault, B. et al., 2014; Villegas, V. et al., 2014).

\section{Treatment:-}

The major purpose of curing the retinoblastoma is the salvation of the vision and to reduce the long-lasting adverse effects of the therapy. The advancement in the therapy has increased the success rate for the survival from almost $30-95 \%$ within last 60 years against the non-metastatic retinoblastoma while the uncured retinoblastoma can be lethal (Bakhshi \& Bakhshi, 2007; Meel, R. et al., 2012). Enucleation, chemotherapy and external beam radiation therapy (EBRT) are the major therapies for the treatment of substantial diseases (Bakhshi \& Bakhshi, 2007).

Enucleationis used often for the treatment of localized retinoblastoma but is risky as the cost is the loss of eyesight in some cases (Shields \& Shields, 2004). Besides its adverse psychological and physiological effects, it is also associated with some long-lasting native effects i.e. contraction of socket, discharge from orbit and extrusion of implant. Therefore, some relatively noninvasive focal ophthalmological therapies are needed (Bakhshi \& Bakhshi, 2007). Approximately 65-75\% unilateral sporadic retinoblastoma can be cured with Enucleation (Epstein, J. et al., 2003).

$\boldsymbol{E B R T}$ - External beam radiation therapy is a mode of treatment of retinoblastoma by delivering whole eye irradiation. As retinoblastoma is a radiosensitive tumor. It may affect the mid-face growth in $90 \%$ patients. Radiation can harm the retina, lens and optic nerve that is difficult to manage (Shields, C. et al., 2013). EBRT usually cause $35 \%$ risk of the secondary tumors in the patients with germ-line RB1 gene mutation. It often leads to the loss of eyesight as well (Epstein, J. et al., 2003).

Chemotherapy has always been a significant mode of all the possible curing methods that does not cause any adverse effects (Shields, C. et al., 2004; Shields, C. et al., 2004). Many drugs like Cisplatin, Adriamycin, Carboplatin, Idarubicin, Etoposide and Cyclophosphamide are being used for the treatment of retinoblastoma. This approach can be used in the treatment by 3 means i.e. Micrometastatic Retinoblastoma, Intraocular Retinoblastoma or Overt Dissemination (Bakhshi \& Bakhshi, 2007).

\section{Autosomal Recessive Monogenic Disorders Metabolism: Cystic Fibrosis}

The most common autosomal inherited recessive monogenic disorder of the glandular epithelial cells present within the human body is cystic fibrosis. Approximately 2000 variations in that gene have been recognized by now (Cleveland, R. et al., 2009). Nearly 70,000 cases have been reported every year on the basis of multi-systemic metabolic disorder (Scott, A. 2013).

\section{Etiology:-}

Cystic fibrosis occurs due to the mutation or change in the CFTR gene i.e. cystic fibrosis trans-membrane conductance regulator, which regulates the mucous and sweat production from the exocrine secretary glands. The mutation of the CFTR leads to various defects in the functioning of CFTR glycoprotein (Hoffman \& Ramsey, 2013; Jones \& Helm, 2009). The cytogenetic location of the cystic fibrosis causing CFTR gene in the human genome is $7 \mathrm{q} 31.2$.

\section{Classification:-}

Cystic fibrosis has been classified into different categorizes on the mutation severity basis in the CFTR gene (Messick, J. 2010). 
Table 9: Classification of Mutations in CFTR

\begin{tabular}{|c|l|}
\hline Class & \multicolumn{1}{c|}{ Mutations } \\
\hline I & Defective Production of CFTR Protein \\
\hline II & Changes in CFTR Protein Maturation \\
\hline III & Defective Regulation of CFTR Protein \\
\hline IV & Decreased Chloride Conductance \\
\hline V & Decreased No. of Functional CFTR Proteins \\
\hline VI & Instability of CFTR Proteins \\
\hline
\end{tabular}

Class I, II \& III are related to the insufficiency of the pancreas along with the CFTR improper expression and functioning as they are much severe while class IV, V and VI are related to the sufficiency of the pancreas and are relatively less severe (Cleveland, R. et al., 2009). In contrast to these classifications, cystic fibrosis can also cause the respiratory as well as the non-respiratory.

\section{Diagnosis:-}

Cystic fibrosis can be easily diagnosed with the help of some biochemical testing and genotyping techniques and biopsy of the patient can also be examined. As the disease shows the various effects upon the different body organs hence, it may cause the confusion in the detection and confirmation of the disease so in that case the differential diagnosis of the suspected diseases can be examined altogether over a single test and the results would confirm the presence of the disorder (Nelms \& Sucher, 2015; Scott, A. 2013).

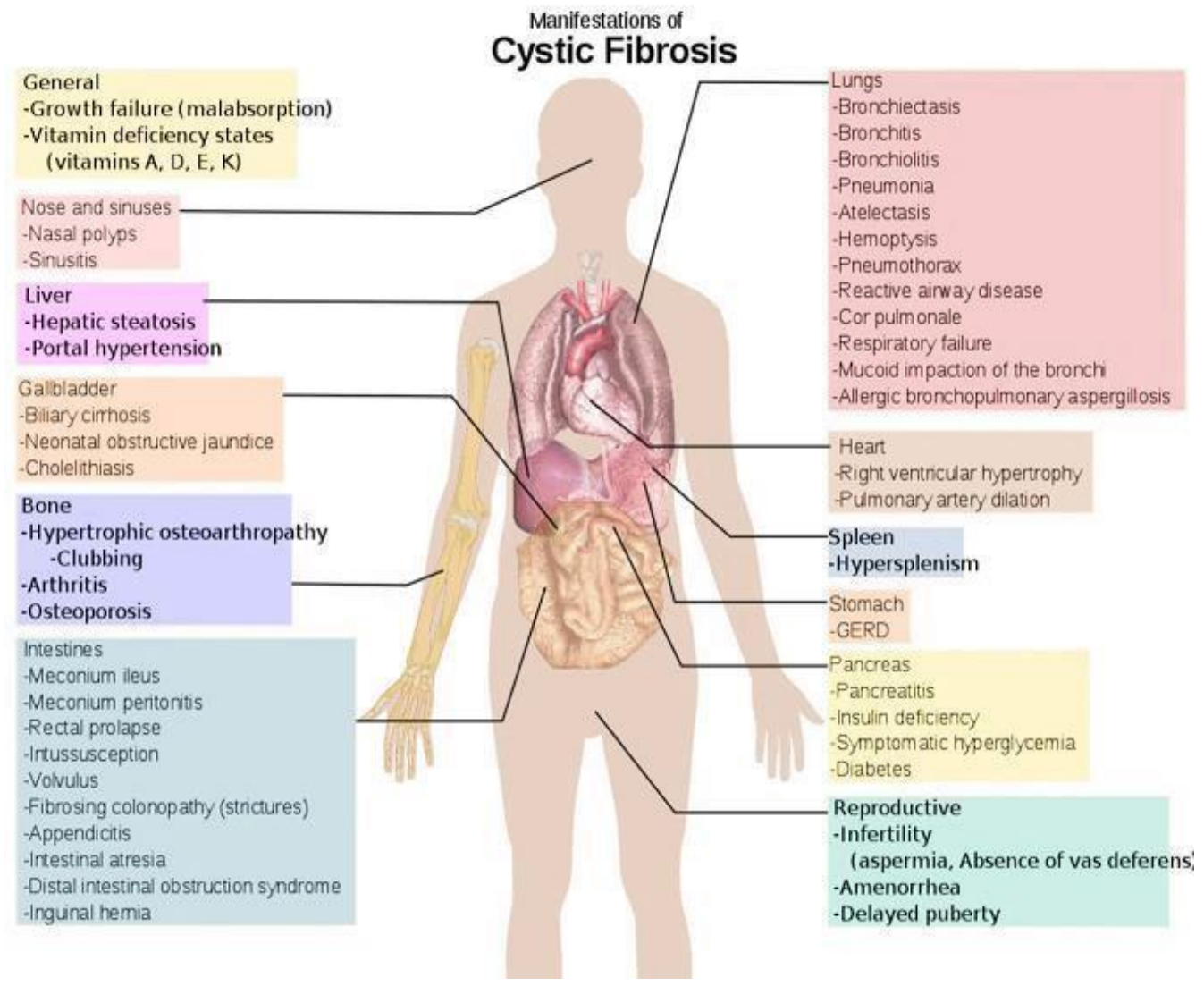

Fig. 10: Organs at risk of Cystic Fibrosis 


\section{Treatment:-}

Cystic fibrosis can be commonly cured by the help of the antibiotic therapy as it play a vital role in the reduction of the inflammatory response that occurs in the result of some chronic bacterial infection (Cohen-Cymberknoh, M. et al., 2013; Elizur, A. et al., 2008). The antibiotics like ibuprofen, glycerin, azithromycin and amphotericin B act as the anti-inflammatory agents (Wiehe \& Arndt, 2010).Chest imaging i.e. High resolution computerized tomography [CT] Scan and the standard chest radiography are also being used for a purpose that is the evaluation of the lung status in the inflammatory stage of the body as it is an organ that is at the high risk of getting disease (Ashlock \& Olson, 2011; Zemanick, E. et al., 2010). Hence, the anti-inflammatory therapy has been introduced in order to treat the lung disease that comes up as the resultant of the cystic fibrosis (Elizur, A. et al., 2008). The treatment of that disease is a huge challenge as it is a cost effective scenario as well as the treatment burden is also unbearable (Hoffman \& Ramsey, 2013; Jones \& Helm, 2009).

\section{Blood Cells: Thalassemia:-}

The most common of the autosomal inherited recessive congenital monogenic disorders is Thalassemia these days. It is an analog of inherited anemia. WHO has reported that approximately 60,000 births take place suffering from the major thalassemia disease on the yearly basis (Aydinok, Y. 2012). Thalassemia is one of the major global public health issues of the socio-economic importance in many countries of the Asia (Fucharoen \& Winichagoon, 2002).

It has been assumed that in the upcoming decade, figure of the Thalassemic births would come around a Million. Out of which $95 \%$ of the cases would be from Asian regions (Cunningham, M. 2008; Vichinsky, E. 2005; Weatherall, D. et al., 2006; Weatherall \& Clegg, 2001).

\section{Normal}

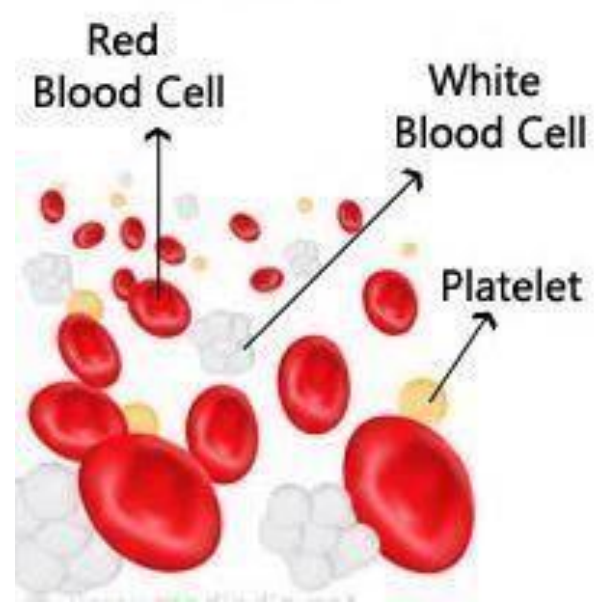

\section{Thalassemia}

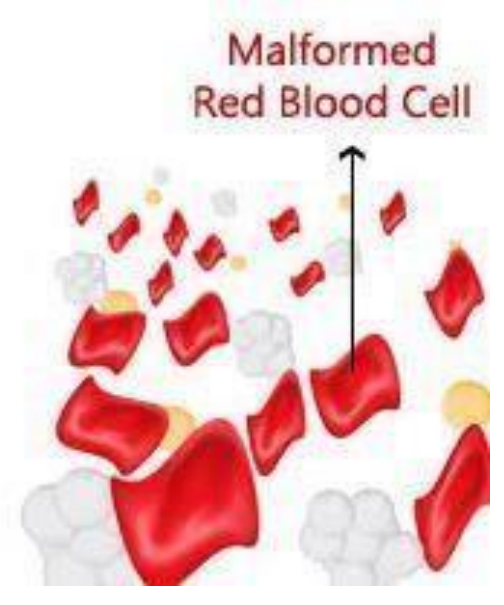

Fig. 11: Effect of Thalassemia on RBCs

\section{Etiology:-}

Thalassemia is actually a class of disorders that happen due to the improper synthesis or the lack of the globin chains of hemoglobin i.e. $\alpha, \beta, \gamma$ and $\delta$ present within the RBCs and performs various body functions (Fucharoen \& Winichagoon, 2002). These changes occur due to the mutation of the Hemoglobin alpha [HBA] or Hemoglobin Beta [HBB] gene that regulates the synthesis of hemoglobin and the mutation in $\alpha$-gene leads to the $\alpha$-Thalassemia while the mutation in the $\beta$-gene leads to the $\beta$-Thalassemia (Cunningham, M. 2010; Hong, C. et al., 2013). The cytogenetic locations of these genes within the human genome are 16p13.3 and 11p15.4.

\section{Classification:-}

The classification of the Thalassemia has been made on the basis of the clinical significances which are mentioned as follows;

1. Severe Thalassemia [Thalassemia Major]

2. Thalassemia Intermedia

3. Asymptotic Thalassemia [Thalassemia Minor] (Fucharoen \& Winichagoon, 2002) 
Table 10: Clinical Features of Thalassemic Patients

\begin{tabular}{|l|l|c|l|}
\hline \multicolumn{1}{|c|}{ Syndromes } & Severity & Hb Level [g/dl] & Mortality Rate \\
\hline Thalassemia Major & Severe anemia & $\leq 6$ & High \\
\hline Thalassemia Intermedia & Mild anemia & 7 & Moderate \\
\hline Thalassemia Minor & Asymptotic anemia & $\geq 9$ & Low \\
\hline
\end{tabular}

\section{Diagnosis:-}

Thalassemia shows some signs and symptoms that are alike the condition of the Iron deficiency. Therefore, in order to get rid of the confusion of these disorders diagnosis, some tests like Red Blood Cell Distribution width [RDW], Mean Corpuscular Volume [MCV] (Muncie \& Campbell, 2009), Peripheral smear, bone marrow aspirate, hemoglobin electrophoresis, serum ferritin \& lead level, family history and differential diagnosis can be examined. All the results of these tests would be relatively lower than that of the iron deficiency condition (Cook, J. 2005; Goddard, A. et al., 2011).

\section{Treatment:-}

The major common remedies against the thalassemia that has been proves successful to some extent are as follows;

Blood Transfusion - The patients suffering from the high severity of this syndrome i.e. thalassemia major tend to need the blood transfusions on the proper schedule throughout the life in order to maintain the blood Hb-level that declines due to the improper globin synthesis and to promote the normal growth (Klein, H. et al., 2007; Olivieri \& Brittenham, 2013; Rund \& Rachmilewitz, 2005; Sornjai, W. et al., 2016).

Endocrinopathy - Growth hormone therapy has been recommended as a variable successful treatment for the $\beta$ thalassemia but it is an often used approach (De Sanctis, V. 2002; Delvecchio \& Cavallo, 2010).

Bone Marrow Transplant - It is the most successful approach of the cure for the thalassemia major, as the precursor of the RBCs i.e. hematopoietic stem cells can be replaced with some healthy ones and ultimately the production of the healthy erythrocytes takes place (Rund \& Rachmilewitz, 2005; Sornjai, W. et al., 2016).

\section{X-Linked Dominant Chromosomal Monogenic Disorders:- Mental Retardation: Fragile X Syndrome:-}

Fragile X Syndrome [FXS] is one of the most rarely occurring congenital X-Linked dominant chromosomal monogenic disorders. This disorder is the cause of learning disability and mental retardation that could be of any stage from mild to moderate and then to the severe in people throughout globe (Garber, K. et al., 2008). Its global prevalence is nearly $1 / 4000$ in males and 1/8000 in the females (Klusek, J. et al., 2014; Sabaratnam, M. 2006; Sabaratnam, M. et al., 2003).

\section{Etiology:-}

FXS usually occurs due to the unexpressed FMR1 gene which encodes the fragile X mental retardation protein [FMRP]. The inexpression results because of the addition of GGG repeats within the 5'-UTR of the gene (Santoro, M. et al., 2012). The cytogenetic location of the FMR1 gene within the human genome is Xq27.3. FMR1 is one of the genes to be cloned for the first time that are related to the human intelligence (Garber, K. et al., 2008).

\section{Diagnosis:-}

FXS can be easily diagnosed by the help of fairly expressed phenotype of the infant. Besides this, the occurrence of the FXS can be confirmed by various genotyping technologies, Southern blot, PCR, microarray and differential diagnosis. The step towards the cure of the disorder can be taken when the cause is known (Hill, M. et al., 2010; Sabaratnam, M. 2006). 


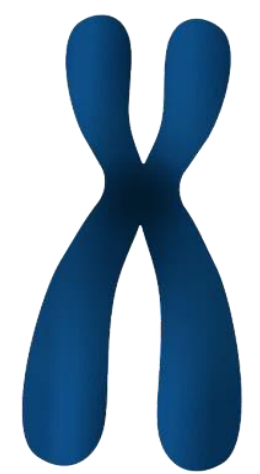

Normal X chromosome

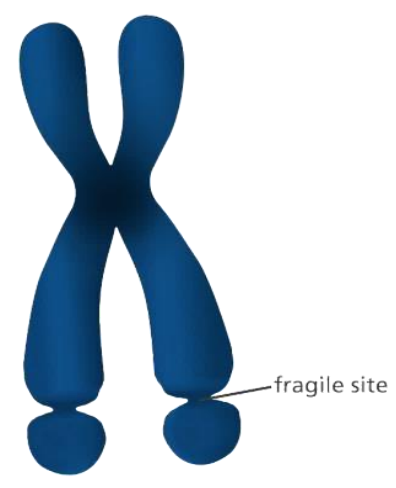

Fragile-X chromosome

Fig. 12: Fragile X Syndrome

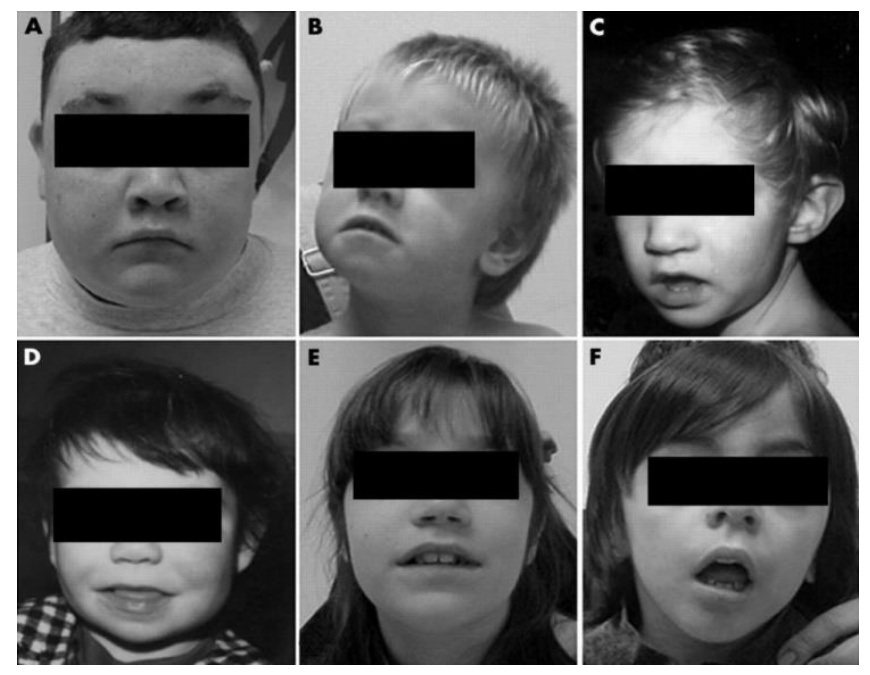

Fig. 13: Autism \& Mental Retardation by FXS

\section{Treatment:-}

The possible cure for the Fragile $\mathrm{X}$ syndrome is based upon the medications that favors the mental relaxation by causing the impulsions, hyperactivity and distractions in the mind (Berry_Kravis \& Potanos, 2004).Selective Serotonin reuptake inhibitors [SSRIs], Ampakine and some other relevant drugs can be proved useful as they are effective against the conditions like anxiety and aggression etc. (Berry-Kravis, E. et al., 2006; Berry_Kravis \& Potanos, 2004; Garber, K. et al., 2008).

\section{Bone: Hypophosphatemia:-}

Hypophosphatemia is an X-linked dominant chromosomal genetic disorder. It refers to the disorder that leads to the depletion in the phosphate level in the blood serum. It is usually uncommon in the population (Brunelli \& Goldfarb, 2007; Felsenfeld \& Levine, 2012). As phosphate is an essential component for many body pathways that includes the plasma $\mathrm{pH}$ maintenance, cellular signaling, skeletal development, bone mineralization, structure of nucleotide and membrane composition (Bacchetta \& Salusky, 2012).

\section{Etiology:-}

The major cause of the hypophosphatemia is the mutation in phosphate regulating endopeptidase gene [PHEX] that regulates the phosphate level in the serum (Bacchetta \& Salusky, 2012). Its cytogenetic location within the human genome is Xp22.11. 


\section{Classification:-}

Hypophosphatemia has been classified on the basis on its affecting duration period as well as the severity. It is mentioned as below;

1. Acute Hypophosphatemia

2. Chronic Hypophosphatemia

Acute Hypophosphatemia is actually due to nosocomial infections and can be significantly morbid as well as mortal and chronic hypophosphatemia is an inborn genetic disorder that promotes the skeletal disorders in the children [rickets] as well as in adults [Osteomalacia] (Felsenfeld \& Levine, 2012). While on the severity basis, the hypophosphatemia can be categorized as;

Table 11: Phosphate Levels in different Hypophosphatemia Stages

\begin{tabular}{|l|c|}
\hline \multicolumn{1}{|c|}{ Hypophosphatemia Severity } & Phosphate Level \\
\hline Mild & $2-2.5 \mathrm{mg} / \mathrm{dL}$ \\
\hline Moderate & $1-1.9 \mathrm{mg} / \mathrm{dL}$ \\
\hline Severe & $1 \mathrm{mg} / \mathrm{dL}$ \\
\hline
\end{tabular}

Diagnosis:-

The hypophosphatemia can be easily diagnosed by the help of its unique signs and symptoms that includes the poor oral intake, increased renal loss and intracellular phosphate redistribution (Boateng, A. et al., 2010; Marinella, M. 2005; Ornstein, R. et al., 2003).

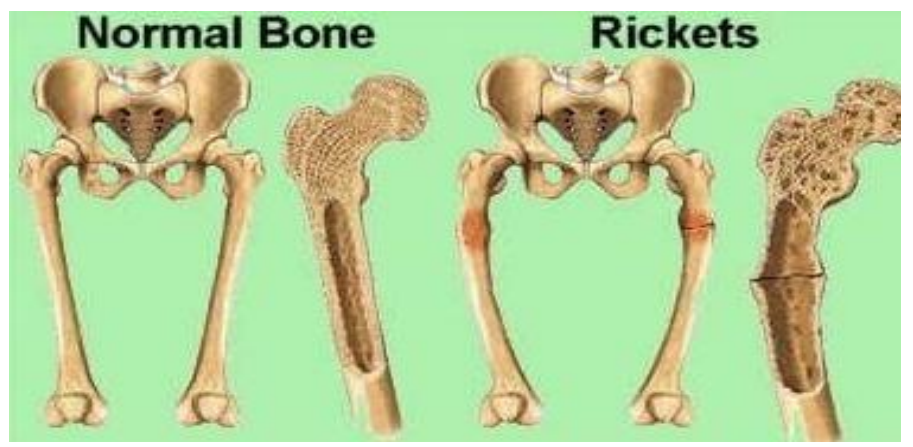

Fig. 14: Rickets due to Hypophosphatemia

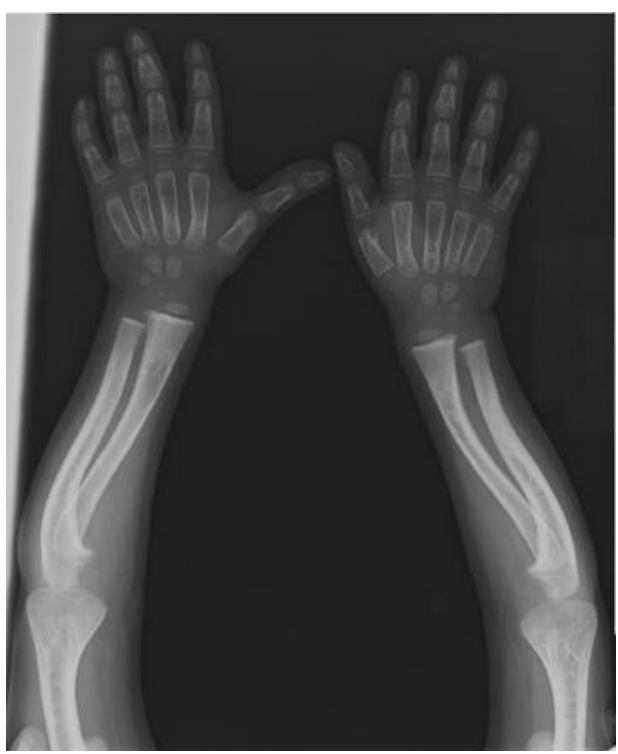

Fig. 15: X-Ray view of the Rickets 


\section{Treatment:-}

The treatment of the hypophosphatemia involves the approaches by which the phosphate depletion can be fulfilled or restored. Direct phosphate oral supplementation, vitamin D intake and the medications like Cinacalcet, Dypyrimadole and Calcitonin helps in treating this disorder. The salts of phosphates can also be used as the supplements for electrolyte balancing (Geerse, D. et al., 2010; Imel \& Econs, 2012; Marinella, M. 2005).

\section{X-Linked Recessive Sex Chromosomal Monogenic Disorders:- Bleeding: Hemophilia:-}

Hemophilia is also a common congenital X-Linked recessive sex chromosomal monogenic bleeding disorder (Caviglia, H. et al., 2015). It has been classified as hemophilia A and hemophilia B due to same outcomes but different causes of the disorder (Jayandharan, G. et al., 2012; Kaufman \& Powell, 2013; Rodriguez \& Hoots, 2010). As the disorders are X-Linked, it affects the males at the most and females can also be the carriers despite of being affected (Plug, I. et al., 2006).The global prevalence of the hemophilia A is 1/5000 in males and of the hemophilia B is 1/30000 in males (Stonebraker, J. et al., 2010; Stonebraker, J. et al., 2012).

\section{Etiology:-}

Hemophilia usually occur due to the lack of factor VIII [F8], in case of hemophilia A or factor IX [F9], in case of hemophilia B (Carcao, M. 2012; Peyvandi, F. et al., 2016). The cytogenetic location of these genes within the human genome is Xq28 and Xq27.1 (Bowen, D. 2002). Both of these genes play a role in the coagulation of blood normally.

\section{Diagnosis:-}

Hemophilia can be diagnosed by the genotyping technologies and via simple blood test for the factors on unit calculation. The prevalence of hemophilia generally gets disturbed by avoiding the mild cases from the count. As it do not usually diagnosed because of its less fatality rate as compared to the moderate and the severe types. This disorder reduces the life span of the patients as well as the prevalence (Bhat \& Cabey, 2014; Carcao, M. 2012; Peyvandi, F. et al., 2016).

\section{Treatment:-}

Various adjunctive therapies have been discovered for the possible cure of the hemophilia including anti-fibrinolytic agents. Prophylaxis is another most successful approach for the cure of hemophilia and is the most ancient one that is being used since last 50 years (Feldman, B. et al., 2006; Gringeri, A. et al., 2011). Gene therapy and the stem cell transplantation are the most recent one approach in the field of the treatment of this very severe, inherited, monogenic and congenital disorder (Chuah, M. et al., 2013).

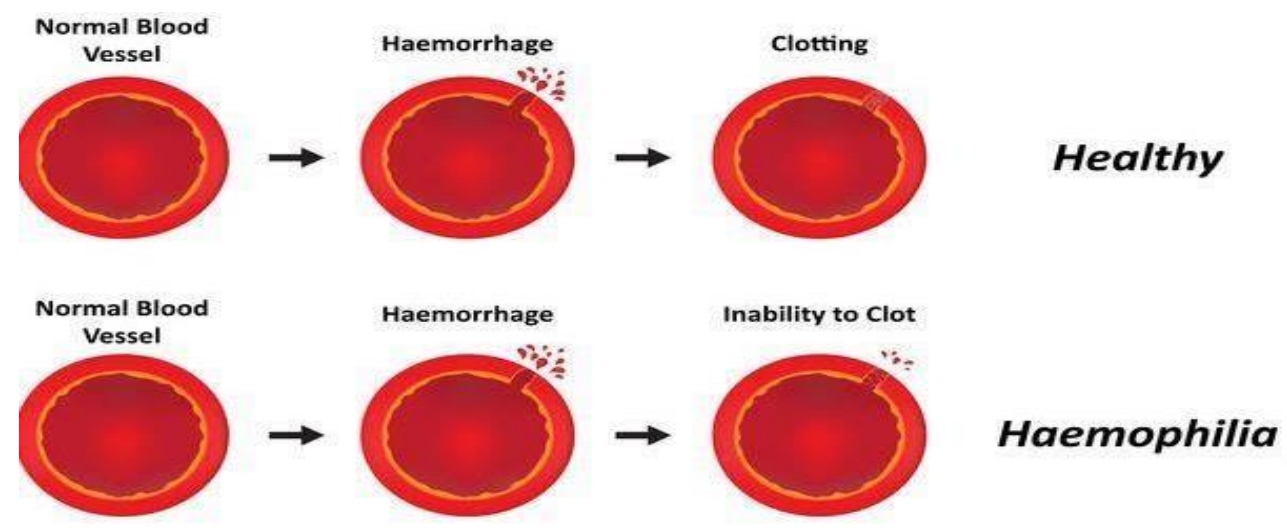

Fig. 16: Effect of Hemophilia on body cells

\section{Skin: Ichthyosis:-}

Ichthyosis is basically a group of skin related disorders that are X-linked recessive sex chromosomal inherited in pattern (Vahlquist, A. et al., 2008).It is most frequent in affecting the males completely whereas the females can also be the carriers of the disorder. It generally leads to the scaling and dryness of the skin with some prominent spotting. 
The global prevalence of the ichthyosis is approximately 1/6000 in males (Fernandes, N. et al., 2010; Oji \& Traupe, 2009).

\section{Etiology:-}

The major cause of the ichthyosis is the mutation in the steroid sulphatase [STS] enzyme. 1,2. Deletion mutations within the gene usually leads to the ichthyosis while almost complete deletion of the gene has been observed in the $90 \%$ of the affected individuals (Fernandes, N. et al., 2010). The cytogenetic location of the STS gene within the human genome is Xp22.31 (Vahlquist, A. et al., 2008).

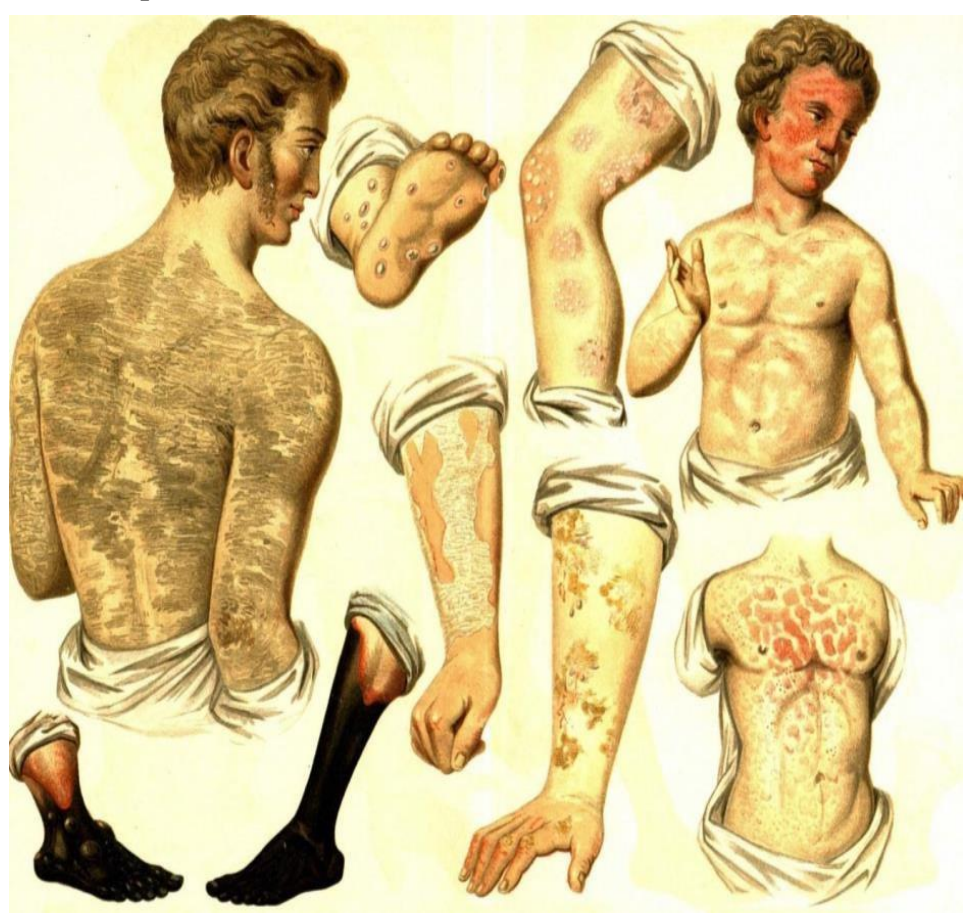

Fig. 17: Effects of Ichthyosis on body

\section{Diagnosis:-}

The genetic and biochemical testing are the most concise diagnostic ways of the ichthyosis (Fernandes, N. et al., 2010).There is a great confusion in the identification of the disorder due to its similar related classified disorders i.e. ichthyosis vulgaris, lamellar ichthyosis and bullous ichthyosis but their causes varies as they are autosomal dependent dominant as well as recessive (DiGiovanna \& Robinson-Bostom, 2003). Hence, the differential diagnosis and the prenatal diagnosis are the most reliable approaches for the detection and confirmation of the disorder in order to take the step towards the appropriate treatment including southern blot (Reed, M. et al., 2005), in-situ hybridization (Chen, H. 2006; Lebo, R. et al., 2013) and PCR (Sugawara, T. et al., 2000), the most commonly used techniques of the molecular biology (Vahlquist, A. et al., 2008).

\section{Treatment:-}

The ichthyosis can be proved lethal while going from mild to the severe stage. The possible cures for getting rid of these disorders include topical therapy, by hydration and lubrication, use of keratolytic agent for enhancement of the skin hydration and the systemic treatment for proper skin functioning i.e. sweat production (DiGiovanna \& Robinson-Bostom, 2003).

\section{Future Prospects:-}

As the monogenic disorders are the most common issues of the society that are usually resulting from the consanguinity can be overcome by applying the precautionary measures to the social acts i.e. marriages. The genetic analysis of the individuals can be performed before performing such acts for avoiding such complications in future. Various detection methods and the possible treatments have been established against these monogenic disorders furthermore, some high throughput technologies are being implemented in this field of health for the fulfillment of the need of treatment. Prenatal diagnosis has also been proved a reliable technique of the diagnosis till now but also causes confusions while the diagnosis with some other resembling diseases. Therefore, the advancements are also 
being made in the field for solving that problem. In the upcoming decade there is a possibility of gradual decrease in the monogenic disorders if preventive measures are done properly. Besides this, if the situation persists then there is equal possibility of the continuous increase in these disorders.

Several biomedical heath related organizations are working on the genetic disorders, monogenic as well as polygenic, for the welfare of mankind. Along with the comprehensive study of these disorders, the public awareness is also being delivered so that the people must know about the complications while developing any decision. The fate of their offspring can be diagnosed whether it is normal or mutated. Recombinant DNA Technology and the techniques of Genetic Engineering are supposed to be beneficial for the most efficient cure of these abnormalities.

\section{References:-}

1. Abramson, D. H., Schefler, A., Albert, D., \& Polans, A. (2003). The treatment of retinoblastoma. Ocular Oncology., 353, 376.

2. Ahmed, N., Dawson, M., Smith, C., \& Wood, E. (2006). Biology of disease: Garland Science.

3. Alberts, B., Johnson, A., Lewis, J., Walter, P., Raff, M., \& Roberts, K. (2002). Molecular Biology of the Cell 4th Edition: International Student Edition: Routledge.

4. Alharbi, S. A. (2016). A Systematic Overview of Osteogenesis Imperfecta. Molecular Biology: Open Access, 2016.

5. Amberger, J. S., Bocchini, C. A., Schiettecatte, F., Scott, A. F., \& Hamosh, A. (2015). OMIM. org: Online Mendelian Inheritance in Man (OMIM®), an online catalog of human genes and genetic disorders. Nucleic acids research, 43(D1), D789-D798.

6. Antonarakis, S. E. (2001). The search for allelic variants that cause monogenic disorders or predispose to common, complex polygenic phenotypes.Dialogues in clinical neuroscience, 3(1), 7.

7. Antonarakis, S. E., \& Beckmann, J. S. (2006). Mendelian disorders deserve more attention. Nature Reviews Genetics, 7(4), 277-282.

8. Ashlock, M. A., \& Olson, E. R. (2011). Therapeutics development for cystic fibrosis: a successful model for a multisystem genetic disease. Annual review of medicine, 62, 107-125.

9. Aslamkhan, M. (2015). Clinical Genetics and Genetic Counselling in Pakistan. Journal of Genes and Cells, $1(2), 31$.

10. Aydinok, Y. (2012). Thalassemia. Hematology, 17 Suppl 1, S28-31. doi: 10.1179/102453312x13336169155295

11. Bacchetta, J., \& Salusky, I. B. (2012). Evaluation of hypophosphatemia: lessons from patients with genetic disorders. American Journal of Kidney Diseases, 59(1), 152-159.

12. Bagheri, M., Rad, I. A., Jazani, N. H., Zarrin, R., \& Ghazavi, A. (2015). Molecular Genetic Analysis of the Variable Number of Tandem-Repeat Alleles at the Phenylalanine Hydroxylase Gene in Iranian Azeri Turkish Population. Iranian biomedical journal, 19(3), 183.

13. Bakhshi, S., \& Bakhshi, R. (2007). Genetics and management of retinoblastoma. Journal of Indian Association of Pediatric Surgeons, 12(3), 109.

14. Bamshad, M. J., Ng, S. B., Bigham, A. W., Tabor, H. K., Emond, M. J., Nickerson, D. A., \& Shendure, J. (2011). Exome sequencing as a tool for Mendelian disease gene discovery. Nature Reviews Genetics, 12(11), 745-755.

15. Barello, S., Menichetti, J., \& Graffigna, G. (2016). Technologies for Participatory Wellbeing: A Consumer Health Analysis of. Integrating Technology in Positive Psychology Practice, 59.

16. Bartuma, K., Pal, N., Kosek, S., Holm, S., \& All_Ericsson, C. (2014). A 10_year experience of outcome in chemotherapy_treated hereditary retinoblastoma.

17. Acta ophthalmologica, 92(5), 404-411.

18. Berry-Kravis, E., Krause, S. E., Block, S. S., Guter, S., Wuu, J., Leurgans, S., Salt, J. (2006). Effect of CX516, an AMPA-Modulating Compound, on Cognition and Behavior in Fragile X Syndrome: AControlled Trial. Journal of Child \& Adolescent Psychopharmacology, 16(5), 525-540.

19. Berry-Kravis, E., \& Potanos, K. (2004). Psychopharmacology in fragile X syndrome: present and future. Mental retardation and developmental disabilities research reviews, 10(1), 42-48.

20. Bhat, R., \& Cabey, W. (2014). Evaluation and management of congenital bleeding disorders. Emergency medicine clinics of North America, 32(3), 673-690.

21. Bittles, A. H. (2012). Consanguinity in context (Vol. 63): Cambridge University Press.

22. Boateng, A. A., Sriram, K., Meguid, M. M., \& Crook, M. (2010). Refeeding syndrome: treatment considerations based on collective analysis of literature case reports. Nutrition, 26(2), 156-167. 
23. Boulard, M., Edwards, J. R., \& Bestor, T. H. (2016). Abnormal X chromosome inactivation and sex-specific gene dysregulation after ablation of FBXL10.

24. Epigenetics \& chromatin, 9(1), 1.

25. Bowen, D. J. (2002). Haemophilia A and haemophilia B: molecular insights. Molecular Pathology, 55(2), 127 144.

26. Bowles, E., Corson, T. W., Bayani, J., Squire, J. A., Wong, N., Lai, P. B. S., \& Gallie, B. L. (2007). Profiling genomic copy number changes in retinoblastoma beyond loss of RB1. Genes, Chromosomes and Cancer, 46(2), 118-129.

27. Brunelli, S. M., \& Goldfarb, S. (2007). Hypophosphatemia: clinical consequences and management. Journal of the American Society of Nephrology, 18(7), 1999-2003.

28. Byers, P. H., Krakow, D., Nunes, M. E., \& Pepin, M. (2006). Genetic evaluation of suspected osteogenesis imperfecta (OI). Genetics in Medicine, 8(6), 383-388.

29. Carcao, M. D. (2012). The diagnosis and management of congenital hemophilia. Paper presented at the Seminars in thrombosis and hemostasis.

30. Cavalli, P. (2009). Genetic counseling: a medical approach. Genetic testing and molecular biomarkers, 13(1), 15.

31. Caviglia, H., Landro, M., Galatro, G., Candela, M., \& Neme, D. (2015). Epidemiology of fractures in patients with haemophilia. Injury, 46(10), 18851890.

32. Chagas, C. E., Roque, J. P., Santarosa Emo Peters, B., Lazaretti-Castro, M., \& Martini, L. A. (2012). Do patients with osteogenesis imperfecta need individualized nutritional support? Nutrition, 28(2), 138-142. doi: 10.1016/j.nut.2011.04.003

33. Chen, H. (2006). X-Linked Ichthyosis. Atlas of Genetic Diagnosis and Counseling, 1057-1060.

34. Chen, N., Van Hout, C. V., Gottipati, S., \& Clark, A. G. (2014). Using Mendelian inheritance to improve highthroughput SNP discovery. Genetics, 198(3), 847-857.

35. Cheung, M. S., Glorieux, F. H., \& Rauch, F. (2007). Natural history of hyperplastic callus formation in osteogenesis imperfecta type V. Journal of Bone and Mineral Research, 22(8), 1181-1186.

36. Chevrel, G. (2004). Osteogenesis imperfecta. Orphanet encyclopedia, June.

37. Chong, J. X., Buckingham, K. J., Jhangiani, S. N., Boehm, C., Sobreira, N., Smith, J. D., Gambin, T. (2015). The genetic basis of Mendelian phenotypes: discoveries, challenges, and opportunities. The American Journal of Human Genetics, 97(2), 199-215.

38. Christian, C. W., Crawford-Jakubiak, J. E., Flaherty, E. G., Leventhal, J. M., Lukefahr, J. L., Sege, R. D., Hurley, T. P. (2015). The evaluation of suspected child physical abuse. Pediatrics, 135(5), e1337-e1354.

39. Chuah, M., Evens, H., \& VandenDriessche, T. (2013). Gene therapy for hemophilia. Journal of Thrombosis and Haemostasis, 11(s1), 99-110.

40. Cleveland, R. H., Zurakowski, D., Slattery, D., \& Colin, A. A. (2009). Cystic Fibrosis Genotype and Assessing Rates of Decline in Pulmonary Status 1. Radiology, 253(3), 813-821.

41. Cohen-Cymberknoh, M., Kerem, E., Ferkol, T., \& Elizur, A. (2013). Airway inflammation in cystic fibrosis: molecular mechanisms and clinical implications. Thorax, 68(12), 1157-1162.

42. Cook, J. D. (2005). Diagnosis and management of iron-deficiency anaemia. Best Practice \& Research Clinical Haematology, 18(2), 319-332.

43. Cunningham, M. J. (2008). Update on thalassemia: clinical care and complications. Pediatric Clinics of North America, 55(2), 447-460.

44. Cunningham, M. J. (2010). Update on thalassemia: clinical care and complications. Hematol Oncol Clin North Am, 24(1), 215-227. doi: 10.1016/j.hoc.2009.11.006

45. Cutting, G. R. (2010). Modifier genes in Mendelian disorders: the example of cystic fibrosis. Annals of the New York Academy of Sciences, 1214(1), 57-69.

46. De Sanctis, V. (2002). Growth and puberty and its management in thalassaemia. Hormone Research in Paediatrics, 58(Suppl. 1), 72-79.

47. Delvecchio, M., \& Cavallo, L. (2010). Growth and endocrine function in thalassemia major in childhood and adolescence. Journal of endocrinological investigation, 33(1), 61-68.

48. DiGiovanna, J. J., \& Robinson-Bostom, L. (2003). Ichthyosis. American journal of clinical dermatology, 4(2), 81-95.

49. Dimaras, H., Khetan, V., Halliday, W., Orlic, M., Prigoda, N. L., Piovesan, B., Squire, J. A. (2008). Loss of RB1 induces non-proliferative retinoma: increasing genomic instability correlates with progression to retinoblastoma. Human molecular genetics, 17(10), 1363-1372. 
50. Dimaras, H., Kimani, K., Dimba, E. A., Gronsdahl, P., White, A., Chan, H. S., \& Gallie, B. L. (2012). Retinoblastoma. Lancet, 379(9824), 1436-1446. doi: 10.1016/s0140-6736(11)61137-9

51. Dobyns, W. B. (2006). The pattern of inheritance of X_linked traits is not dominant or recessive, just X_linked. Acta Paediatrica, 95(S451), 11-15.

52. Dobyns, W. B., Filauro, A., Tomson, B. N., Chan, A. S., Ho, A. W., Ting, N. T., Ober, C. (2004). Inheritance of most X_linked traits is not dominant or recessive, just X_linked. American Journal of Medical Genetics Part A, 129(2), 136-143.

53. Dogba, M. J., Dahan-Oliel, N., Snider, L., Glorieux, F. H., Durigova, M., Palomo, T., Rauch, F. (2016). Involving Families with Osteogenesis Imperfecta in Health Service Research: Joint Development of the OI/ECE Questionnaire. PloS one, 11(1), e0147654.

54. Dogba, M. J., Rauch, F., Douglas, E., \& Bedos, C. (2014). Impact of three genetic musculoskeletal diseases: a comparative synthesis of achondroplasia, Duchenne muscular dystrophy and osteogenesis imperfecta. Health and quality of life outcomes, 12(1), 1.

55. Dongen, J. v. (2015). (Epi) genetics and twins.

56. Duncan, E., Brown, M., \& Shore, E. M. (2014). The revolution in human monogenic disease mapping. Genes, 5(3), 792-803.

57. Elizur, A., Cannon, C. L., \& Ferkol, T. W. (2008). Airway inflammation in cystic fibrosis. CHEST Journal, 133(2), 489-495.

58. Epstein, J. A., Shields, C. L., \& Shields, J. A. (2003). Trends in the management of retinoblastoma: evaluation of 1,196 consecutive eyes during 1974 to 2001 .

59. Journal of pediatric ophthalmology and strabismus, 40(4), 196-203.

60. Feldman, B., Pai, M., Rivard, G., Israels, S., POON, M. C., Demers, C., Gill, K. (2006). Tailored prophylaxis in severe hemophilia A: interim results from the first 5 years of the Canadian Hemophilia Primary Prophylaxis Study. Journal of Thrombosis and Haemostasis, 4(6), 1228-1236.

61. Felsenfeld, A. J., \& Levine, B. S. (2012). Approach to treatment of hypophosphatemia. American Journal of Kidney Diseases, 60(4), 655-661.

62. Fernandes, N. F., Janniger, C. K., \& Schwartz, R. A. (2010). X-linked ichthyosis: an oculocutaneous genodermatosis. Journal of the American Academy of Dermatology, 62(3), 480-485.

63. Fiorentino, F., Biricik, A., Nuccitelli, A., De Palma, R., Kahraman, S., Iacobelli, M., Borini, A. (2005). Strategies and clinical outcome of 250 cycles of Preimplantation Genetic Diagnosis for single gene disorders. Human Reproduction.

64. Fountain, E. D., Pauli, J. N., Reid, B. N., Palsbøll, P. J., \& Peery, M. Z. (2016). Finding the right coverage: the impact of coverage and sequence quality on single nucleotide polymorphism genotyping error rates. Molecular ecology resources.

65. Fucharoen, S., \& Winichagoon, P. (2002). Thalassemia and abnormal hemoglobin. International journal of hematology, 76(2), 83-89.

66. Gao, Z., Waggoner, D., Stephens, M., Ober, C., \& Przeworski, M. (2015). An estimate of the average number of recessive lethal mutations carried by humans. Genetics, 199(4), 1243-1254.

67. Garber, K. B., Visootsak, J., \& Warren, S. T. (2008). Fragile X syndrome. European Journal of Human Genetics, 16(6), 666-672.

68. Geerse, D. A., Bindels, A. J., Kuiper, M. A., Roos, A. N., Spronk, P. E., \& Schultz, M. J. (2010). Treatment of hypophosphatemia in the intensive care unit: a review. Critical Care, 14(4), 1.

69. Ghassemi, F., Chams, H., Sabour, S., Karkhaneh, R., Farzbod, F., Khodaparast, M., \& Vosough, P. (2014). Characteristics of Germline and Non-germline Retinoblastomas. Journal of Ophthalmic \& Vision Research, 9(2), 188-194.

70. Gialluisi, A., Pippucci, T., Anikster, Y., Ozbek, U., Medlej-Hashim, M., Mégarbané, A., \& Romeo, G. (2012). Estimating the allele frequency of autosomal recessive disorders through mutational records and consanguinity: the homozygosity index (HI). Annals of human genetics, 76(2), 159-167.

71. Glorieux, F. H., Rauch, F., Plotkin, H., Ward, L., Travers, R., Roughley, P., Bishop, N. J. (2000). Type V osteogenesis imperfecta: a new form of brittle bone disease. Journal of Bone and Mineral Research, 15(9), 1650-1658.

72. Glorieux, F. H., Ward, L. M., Rauch, F., Lalic, L., Roughley, P. J., \& Travers, R. (2002). Osteogenesis imperfecta type VI: a form of brittle bone disease with a mineralization defect. J Bone Miner Res, 17(1), 30-38. doi: 10.1359/jbmr.2002.17.1.30

73. Goddard, A. F., James, M. W., McIntyre, A. S., \& Scott, B. B. (2011). Guidelines for the management of iron deficiency anaemia. Gut, gut. 2010.228874. 
74. Gringeri, A., Lundin, B., Von Mackensen, S., Mantovani, L., \& Mannucci, P. (2011). A randomized clinical trial of prophylaxis in children with hemophilia A (the ESPRIT Study). Journal of Thrombosis and Haemostasis, 9(4), 700-710.

75. Hadi, S. (2015). Analysis of Rapidly Mutating Y Chromosome Short Tandem Repeats (RM Y-STRs). Methods in molecular biology (Clifton, NJ), 1420, 201-211.

76. Halim, N. B., Bouafif, N. B. A., Romdhane, L., Atig, R. K. B., Chouchane, I., Bouyacoub, Y., Talmoudi, F. (2013). Consanguinity, endogamy, and genetic disorders in Tunisia. Journal of community genetics, 4(2), 273284.

77. Hanahan, D., \& Weinberg, R. A. (2011). Hallmarks of cancer: the next generation. cell, 144(5), 646-674.

78. Harlap, S., Kleinhaus, K., Perrin, M., Calderon-Margalit, R., Paltiel, O., Deutsch, L., Friedlander, Y. (2008). Consanguinity and birth defects in the jerusalem perinatal study cohort. Human heredity, 66(3), 180-189.

79. Harper, J. C., \& SenGupta, S. B. (2012). Preimplantation genetic diagnosis: state of the art 2011. Human genetics, 131(2), 175-186.

80. Henderson, B., Isaac, N., Mabele, O., Khiba, S., Nkayi, A., \& Mokoena, T. (2016). Pamidronate treatment for osteogenesis imperfecta in black South Africans. South African Medical Journal, 106(6), S47.

81. Henn, B. M., Botigue, L. R., Peischl, S., Dupanloup, I., Lipatov, M., Maples, B. K., Snyder, M. P. (2016). Distance from sub-Saharan Africa predicts mutational load in diverse human genomes. Proceedings of the National Academy of Sciences, 113(4), E440-E449.

82. Hill, M. K., Archibald, A. D., Cohen, J., \& Metcalfe, S. A. (2010). A systematic review of population screening for fragile X syndrome. Genetics in Medicine, 12(7), 396-410.

83. Hoffman, L. R., \& Ramsey, B. W. (2013). Cystic fibrosis therapeutics: the road ahead. CHEST Journal, 143(1), 207-213.

84. Hong, C. R., Kang, H. J., Lee, J. W., Kim, H., Kim, N. H., Park, K. D., Ahn, H. S. (2013). Clinical characteristics of pediatric thalassemia in Korea: a single institute experience. J Korean Med Sci, 28(11), 16451649. doi: 10.3346/jkms.2013.28.11.1645

85. Hudson, T. J., Anderson, W., Artez, A., Barker, A. D., Bell, C., Bernabe, R. R., Yang, H. (2010). International network of cancer genome projects. Nature, 464(7291), 993-998. doi: 10.1038/nature08987

86. Hussain, R., Bittles, A., \& Sullivan, S. (2001). Consanguinity and early mortality in the Muslim populations of India and Pakistan. American Journal of Human Biology, 13(6), 777-787.

87. Iida, Y., Kazuki, Y., Hayashi, M., Ueda, Y., Hasegawa, M., Kouprina, N., Oshimura, M. (2014). A bi-HAC vector system towards gene and cell therapy. ACS synthetic biology, 3(2), 83-90. doi: 10.1021/sb400166j

88. Imel, E. A., \& Econs, M. J. (2012). Approach to the hypophosphatemic patient. The Journal of Clinical Endocrinology \& Metabolism, 97(3), 696-706.

89. Irfan-Maqsood, M. (2015). First Year of Successfully Publishing Journal of Genes and Cells. Journal of Genes and Cells, 1(4), 71-72.

90. Jayandharan, G. R., Srivastava, A., \& Srivastava, A. (2012). Role of molecular genetics in hemophilia: from diagnosis to therapy. Paper presented at the Seminars in thrombosis and hemostasis.

91. Jones, A. M., \& Helm, J. M. (2009). Emerging treatments in cystic fibrosis. Drugs, 69(14), 1903-1910.

92. Jonker, M. A., Teeuw, M. E., Kelmemi, W., Kharrat, M., Chaabouni-Bouhamed, H., \& Ten Kate, L. P. (2015). Estimating the Total Pathogenic Allele Frequency of Autosomal Recessive Disorders in Case of Consanguinity. Human heredity, 80(2), 69-78.

93. Kashyap, M. V., Nolan, M., Sprouse, M., Chakraborty, R., Cross, D., Roby, R., \& Vishwanatha, J. K. (2015). Role of genomics in eliminating health disparities. Journal of carcinogenesis, 14(1), 6.

94. Kaufman, R. J., \& Powell, J. S. (2013). Molecular approaches for improved clotting factors for hemophilia. Blood, 122(22), 3568-3574.

95. Klein, H. G., Spahn, D. R., \& Carson, J. L. (2007). Red blood cell transfusion in clinical practice. The Lancet, 370(9585), 415-426.

96. Klusek, J., Martin, G., \& Losh, M. (2014). Consistency between research and clinical diagnoses of autism among boys and girls with fragile X syndrome. Journal of Intellectual Disability Research, 58(10), 940-952.

97. Kosztolányi, G. (2011). Hypothesis: epigenetic effects will require a review of the genetics of child development. Journal of community genetics, 2(2), 91-96. doi: 10.1007/s12687-011-0044-2

98. Kumar, D. (2012). Genetic disorders of the Indian subcontinent: Springer Science \& Business Media.

99. Lacey, S., Chung, J. Y., \& Lin, H. (2014). A comparison of whole genome sequencing with exome sequencing for family-based association studies. Paper presented at the BMC proceedings.

100.Lakhoo, K., \& Sowerbutts, H. (2010). Neonatal tumours. Pediatric surgery international, 26(12), 1159-1168. 
101.Lalonde, E., Albrecht, S., Ha, K. C., Jacob, K., Bolduc, N., Polychronakos, C., Jabado, N. (2010). Unexpected allelic heterogeneity and spectrum of mutations in Fowler syndrome revealed by next-generation exome sequencing. Hum Mutat, 31(8), 918-923. doi: 10.1002/humu.21293

102.Lebo, R. V., Milunsky, A., \& Wyandt, H. E. (2013). Optimizing genome-wide mutation analysis of chromosomes and genes: Google Patents.

103.Li, F., Wang, X., \& Niyibizi, C. (2010). Bone marrow stromal cells contribute to bone formation following infusion into femoral cavities of a mouse model of osteogenesis imperfecta. Bone, 47(3), 546-555.

104.Lindahl, K., Langdahl, B., Ljunggren, Ö., \& Kindmark, A. (2014). THERAPY OF ENDOCRINE DISEASE: Treatment of osteogenesis imperfecta in adults. European Journal of Endocrinology, 171(2), R79-R90.

105.Luo, C., \& Deng, Y. (2013). Retinoblastoma: concerning its initiation and treatment. International Journal of Ophthalmology, 6(3), 397-401. doi:10.3980/j.issn.2222-3959.2013.03.26

106.MacCarthy, A., Bayne, A. M., Brownbill, P. A., Bunch, K. J., Diggens, N. L., Draper, G. J., . . . Murphy, M. F. G. (2013). Second and subsequent tumours among 1927 retinoblastoma patients diagnosed in Britain 19512004. British Journal of Cancer, 108(12), 2455-2463. doi: 10.1038/bjc.2013.228

107.Madu, A. E., \& Olamijulo, J. A. (2013). Pregnancy complicated by a severe form of foetal osteogenesis imperfecta in a 17-year-old primigravida: case report and overview of literature. The Journal of Maternal-Fetal \& Neonatal Medicine, 26(7), 703-705.

108.Marchong, M. N., Yurkowski, C., Ma, C., Spencer, C., Pajovic, S., \& Gallie, B. L. (2010). Cdh11 acts as a tumor suppressor in a murine retinoblastoma model by facilitating tumor cell death. PLoS Genet, 6(4), e1000923. doi: 10.1371/journal.pgen.1000923

109.Marinella, M. A. (2005). Refeeding syndrome and hypophosphatemia. Journal of intensive care medicine, 20(3), 155-159.

110.Marini, J. C., Reich, A., \& Smith, S. M. (2014). Osteogenesis Imperfecta due to Mutations in Non-Collagenous Genes-Lessons in the Biology of Bone Formation. Current opinion in pediatrics, 26(4), 500.

111.McPherson, E. (2006). Genetic diagnosis and testing in clinical practice. Clinical medicine \& research, 4(2), 123-129.

112.Meel, R., Radhakrishnan, V., \& Bakhshi, S. (2012). Current therapy and recent advances in the management of retinoblastoma. Indian Journal of Medical and Paediatric Oncology, 33(2), 80.

113.Mendoza, P. R., \& Grossniklaus, H. E. (2015). Chapter Thirty-The Biology of Retinoblastoma. Progress in molecular biology and translational science, 134, 503-516.

114. Messick, J. (2010). A 21st-century approach to cystic fibrosis: optimizing outcomes across the disease spectrum. Journal of pediatric gastroenterology and nutrition, 51, S1-7; quiz 3 p following S7.

115.Mohd Khalid, M. K. N., Yakob, Y., Md Yasin, R., Wee Teik, K., Gaik Siew, C. n., Rahmat, J., Alagaratnam, J. (2015). Spectrum of germ-line RB1 gene mutations in Malaysian patients with retinoblastoma. Molecular Vision, 21, 1185-1190.

116. Muncie Jr, H. L., \& Campbell, J. (2009). Alpha and beta thalassemia. American family physician, 80(4), 339344.

117.Nash, B. M., Wright, D. C., Grigg, J. R., Bennetts, B., \& Jamieson, R. V. (2015). Retinal dystrophies, genomic applications in diagnosis and prospects for therapy. Translational pediatrics, 4(2), 139.

118. Nelms, M., \& Sucher, K. P. (2015). Nutrition therapy and pathophysiology: Nelson Education.

119. O'Connor, T. P., \& Crystal, R. G. (2006). Genetic medicines: treatment strategies for hereditary disorders. Nature Reviews Genetics, 7(4), 261-276.

120.O Oesullivan, E., van der Kamp, S., Kilbane, M., \& McKenna, M. (2014). Osteogenesis imperfecta in adults: phenotypic characteristics and response to treatment in an Irish cohort. Irish journal of medical science, 183(2), 225-230.

121. Obeidat, B. R., Khader, Y. S., Amarin, Z. O., Kassawneh, M., \& Al Omari, M. (2010). Consanguinity and adverse pregnancy outcomes: the north of Jordan experience. Maternal and child health journal, 14(2), $283-289$.

122.Oji, V., \& Traupe, H. (2009). Ichthyosis. American journal of clinical dermatology, 10(6), 351-364.

123. Oleinikov, A. V. (2008). Microarray synthesis and assembly of gene-length polynucleotides: Google Patents.

124. Olivieri, N. F., \& Brittenham, G. M. (2013). Management of the Thalassemias. Cold Spring Harbor perspectives in medicine, 3(6), a011767.

125.Ornstein, R. M., Golden, N. H., Jacobson, M. S., \& Shenker, I. R. (2003). Hypophosphatemia during nutritional rehabilitation in anorexia nervosa: implications for refeeding and monitoring. Journal of adolescent health, 32(1), 83-88.

126.Pagon, R. A. (2002). Genetic testing for disease susceptibilities: consequences for genetic counseling. Trends in Molecular Medicine, 8(6), 306-307. 
127.Pan, X., \& Weissman, S. M. (2002). An approach for global scanning of single nucleotide variations. Proceedings of the National Academy of Sciences, 99(14), 9346-9351.

128.Pauley, P., Matthews, B. G., Wang, L., Dyment, N. A., Matic, I., Rowe, D. W., \& Kalajzic, I. (2014). Local transplantation is an effective method for cell delivery in the osteogenesis imperfecta murine model. International orthopaedics, 38(9), 1955-1962.

129.Pemberton, T. J., Absher, D., Feldman, M. W., Myers, R. M., Rosenberg, N. A., \& Li, J. Z. (2012). Genomic patterns of homozygosity in worldwide human populations. The American Journal of Human Genetics, 91(2), 275-292.

130.Pembrey, M. (2010). An Introduction to Genetics and Epigenetics of Human Disease. 9-15.

131.Perry, S. E., Hockenberry, M. J., Lowdermilk, D. L., \& Wilson, D. (2014). Maternal child nursing care: Elsevier Health Sciences.

132.Peyvandi, F., Garagiola, I., \& Young, G. (2016). The past and future of haemophilia: diagnosis, treatments, and its complications. The Lancet.

133.Plotkin, H., Rauch, F., Bishop, N. J., Montpetit, K., Ruck-Gibis, J., Travers, R., \& Glorieux, F. H. (2000). Pamidronate Treatment of Severe Osteogenesis Imperfecta in Children under 3 Years of Age 1. The Journal of Clinical Endocrinology \& Metabolism, 85(5), 1846-1850.

134.Plug, I., Mauser-Bunschoten, E. P., Bröcker-Vriends, A. H., van Amstel, H. K. P., van der Bom, J. G., van Diemen-Homan, J. E., Rosendaal, F. R. (2006). Bleeding in carriers of hemophilia. Blood, 108(1), 52-56.

135.Pommerenke, C., Geffers, R., Bunk, B., Bhuju, S., Eberth, S., Drexler, H. G., \& Quentmeier, H. (2016). Enhanced whole exome sequencing by higher DNA insert lengths. BMC genomics, 17(1), 1.

136.Primorac, D., Rowe, D. W., Mottes, M., Barisic, I., Anticevic, D., Mirandola, S., Glorieux, F. H. (2001). Osteogenesis imperfecta at the beginning of bone and joint decade. Croatian medical journal, 42(4), 393-415.

137.Rappaport, H. (2003). Queen Victoria: A biographical companion: Abc-clio.

138.Rauch, F., Moffatt, P., Cheung, M., Roughley, P., Lalic, L., Lund, A. M., Glorieux, F. H. (2013). Osteogenesis imperfecta type V: marked phenotypic variability despite the presence of the IFITM5 c. $-14 \mathrm{C}>\mathrm{T}$ mutation in all patients. Journal of medical genetics, 50(1), 21-24.

139.Reed, M., Purohit, A., Woo, L., Newman, S. P., \& Potter, B. V. (2005). Steroid sulfatase: molecular biology, regulation, and inhibition. Endocrine reviews, 26(2), 171-202.

140.Regalado, E., Medrek, S., Tran_Fadulu, V., Guo, D. C., Pannu, H., Golabbakhsh, H., Kim, D. H. (2011). Autosomal dominant inheritance of a predisposition to thoracic aortic aneurysms and dissections and intracranial saccular aneurysms. American Journal of Medical Genetics Part A, 155(9), 2125-2130.

141.Rodriguez, N. I., \& Hoots, W. K. (2010). Advances in hemophilia: experimental aspects and therapy. Hematol Oncol Clin North Am, 24(1), 181-198.

142.Ropers, H. (2007). New perspectives for the elucidation of genetic disorders. The American Journal of Human Genetics, 81(2), 199-207.

143. Roughley, P. J., Rauch, F., \& Glorieux, F. H. (2003). Osteogenesis imperfecta-clinical and molecular diversity. Eur Cell Mater, 5, 41-47; discussion 47.

144.Rund, D., \& Rachmilewitz, E. (2005). $\beta$-Thalassemia. New England Journal of Medicine, 353(11), $1135-1146$.

145.Rushlow, D. E., Mol, B. M., Kennett, J. Y., Yee, S., Pajovic, S., Thériault, B. L., Corson, T. W. (2013). Characterisation of retinoblastomas without RB1 mutations: genomic, gene expression, and clinical studies. The lancet oncology, 14(4), 327-334.

146.Sabaratnam, M. (2006). Fragile-X syndrome. Psychiatry, 5(9), 325-330.

147.Sabaratnam, M., Murthy, N. V., Wijeratne, A., Buckingham, A., \& Payne, S. (2003). Autistic-like behaviour profile and psychiatric morbidity in Fragile X Syndrome. European child \& adolescent psychiatry, 12(4), 172177.

148.Sandridge, A., Takeddin, J., Al-Kaabi, E., \& Frances, Y. (2010). Consanguinity in Qatar: knowledge, attitude and practice in a population born between 1946 and 1991. Journal of biosocial science, 42(01), 59-82.

149.Santoro, M. R., Bray, S. M., \& Warren, S. T. (2012). Molecular mechanisms of fragile X syndrome: a twentyyear perspective. Annual Review of Pathology: Mechanisms of Disease, 7, 219-245.

150.Scott, A. (2013). Cystic fibrosis. Radiol Technol, 84(5), 493-513; quiz 514-498.

151.Selistre, S. G. A., Maestri, M. K., Santos-Silva, P., Schüler-Faccini, L., Guimarães, L. S. P., Giacomazzi, J., Ashton-Prolla, P. (2016). Retinoblastoma in a pediatric oncology reference center in Southern Brazil. BMC Pediatrics, 16, 48. doi: 10.1186/s12887-016-0579-9

152.Shapiro, J. R., Byers, P. H., Glorieux, F. H., \& Sponseller, P. (2013). Osteogenesis imperfecta: a translational approach to brittle bone disease: Academic Press. 
153.Sheridan, E., Wright, J., Small, N., Corry, P. C., Oddie, S., Whibley, C., McKinney, P. A. (2013). Risk factors for congenital anomaly in a multiethnic birth cohort: an analysis of the Born in Bradford study. The Lancet, 382(9901), 1350-1359.

154.Shields, C. L., Fulco, E. M., Arias, J. D., Alarcon, C., Pellegrini, M., Rishi, P., Shields, J. A. (2013). Retinoblastoma frontiers with intravenous, intra-arterial, periocular, and intravitreal chemotherapy. Eye (Lond), 27(2), 253-264. doi: 10.1038/eye.2012.175

155.Shields, C. L., Mashayekhi, A., Cater, J., Shelil, A., Meadows, A. T., \& Shields, J. A. (2004). Chemoreduction for retinoblastoma. Analysis of tumor control and

156.risks for recurrence in 457 tumors. American journal of ophthalmology, 138(3), 329-337.

157.Shields, C. L., Mashayekhi, A., Luo, C. K., Materin, M. A., \& Shields, J. A. (2015). Optical coherence tomography in children: analysis of 44 eyes with intraocular tumors and simulating conditions. Journal of pediatric ophthalmology and strabismus, 41(6), 338-344.

158.Shields, C. L., Meadows, A. T., Leahey, A. M., \& Shields, J. A. (2004). Continuing challenges in the management of retinoblastoma with chemotherapy. Retina, 24(6), 849-862.

159.Shields, C. L., \& Shields, J. A. (2004). Diagnosis and management of retinoblastoma. Cancer control, 11(5), 317-327.

160.Shigemizu, D., Momozawa, Y., Abe, T., Morizono, T., Boroevich, K. A., Takata, S., Tsunoda, T. (2015). Performance comparison of four commercial human whole-exome capture platforms. Scientific reports, 5.

161.Sornjai, W., Jaratsittisin, J., Khungwanmaythawee, K., Svasti, S., Fucharoen, S., Lithanatudom, P., \& Smith, D. R. (2016). Dysregulation of ferroportin gene expression in $\beta 0$-thalassemia/Hb E disease. Annals of hematology, 95(3), 387396.

162.Stonebraker, J., Bolton_Maggs, P., Michael Soucie, J., Walker, I., \& Brooker, M. (2010). A study of variations in the reported haemophilia A prevalence around the world. Haemophilia, 16(1), 20-32.

163.Stonebraker, J. S., Bolton_Maggs, P. H., Michael Soucie, J., Walker, I., \& Brooker, M. (2012). A study of variations in the reported haemophilia B prevalence around the world. Haemophilia, 18(3), e91-e94.

164.Sugawara, T., Shimizu, H., Hoshi, N., Fujimoto, Y., Nakajima, A., \& Fujimoto, S. (2000). PCR diagnosis of Xlinked ichthyosis: Identification of a novel mutation(E 560 P) of the steroid sulfatase gene. Hum Mutat, 15(3), 296-296.

165.Tao, J., Li, N., Jia, H., Liu, Z., Li, X., Song, J., Zhu, J. (2015). Correlation between genotype and the tetrahydrobiopterin-responsive phenotype in Chinese patients with phenylketonuria. Pediatric research.

166.Terao, C., Yoshifuji, H., Yamano, Y., Kojima, H., Yurugi, K., Miura, Y., Matsuda, F. (2016). Genotyping of relapsing polychondritis identified novel susceptibility HLA alleles and distinct genetic characteristics from other rheumatic diseases. Rheumatology (Oxford). doi: 10.1093/rheumatology/kew233

167.Thériault, B. L., Dimaras, H., Gallie, B. L., \& Corson, T. W. (2014). The genomic landscape of retinoblastoma: a review. Clinical \& experimental ophthalmology, 42(1), 33-52.

168. Thornhill, A. R., Handyside, A. H., Ottolini, C., Natesan, S. A., Taylor, J., Sage, K., Konstantinidis, M. (2015). Karyomapping-a comprehensive means of simultaneous monogenic and cytogenetic PGD: comparison with standard approaches in real time for Marfan syndrome. Journal of assisted reproduction and genetics, 32(3), 347-356.

169.Tuomi, T., Santoro, N., Caprio, S., Cai, M., Weng, J., \& Groop, L. (2014). The many faces of diabetes: a disease with increasing heterogeneity. The Lancet, 383(9922), 1084-1094.

170.Vahlquist, A., Gånemo, A., \& Virtanen, M. (2008). Congenital ichthyosis: an overview of current and emerging therapies. Acta dermato-venereologica, 88(1), 4-14.

171. Valencia, C. A., Husami, A., Holle, J., Johnson, J. A., Qian, Y., Mathur, A., Meng, H. (2015). Clinical impact and cost-effectiveness of whole exome sequencing as a diagnostic tool: a pediatric centeres experience. Frontiers in pediatrics, 3 .

172. Valencia, C. A., Husami, A., Holle, J., Johnson, J. A., Qian, Y., Mathur, A., Zhang, K. (2015). Clinical Impact and Cost-Effectiveness of Whole Exome Sequencing as a Diagnostic Tool: A Pediatric Center's Experience. Front Pediatr, 3, 67. doi: 10.3389/fped.2015.00067

173.Van Dijk, F., \& Sillence, D. (2014). Osteogenesis imperfecta: clinical diagnosis, nomenclature and severity assessment. American Journal of Medical Genetics Part A, 164(6), 1470-1481.

174. Vichinsky, E. P. (2005). Changing patterns of thalassemia worldwide. Annals of the New York Academy of Sciences, 1054(1), 18-24.

175.Villegas, V. M., Gold, A. S., Wildner, A., Ehlies, F., \& Murray, T. G. (2014). Genomic landscape of retinoblastoma. Clinical \& experimental ophthalmology, 42(1), 2-3. 
176.Ward, L. M., Rauch, F., Travers, R., Chabot, G., Azouz, E. M., Lalic, L., Glorieux, F. H. (2002). Osteogenesis imperfecta type VII: an autosomal recessive form of brittle bone disease. Bone, 31(1), 12-18.

177.Warsy, A. S., Al-Jaser, M. H., Albdass, A., Al-Daihan, S., \& Alanazi, M. (2014). Is consanguinity prevalence decreasing in Saudis?: A study in two generations. African health sciences, 14(2), 314-321.

178. Weatherall, D., Akinyanju, O., Fucharoen, S., Olivieri, N., \& Musgrove, P. (2006). Inherited disorders of hemoglobin.

179. Weatherall, D., \& Clegg, J. (2001). Inherited haemoglobin disorders: an increasing global health problem. Bulletin of the World Health Organization, 79(8), 704712.

180.Wekre, L. L., Eriksen, E. F., \& Falch, J. A. (2011). Bone mass, bone markers and prevalence of fractures in adults with osteogenesis imperfecta. Archives of osteoporosis, 6(1-2), 31-38.

181.Wiehe, M., \& Arndt, K. (2010). Cystic fibrosis: a systems review. Aana j, 78(3), 246251.

182.Williams, S., Hughes, T., Adler, C., Brook, A., \& Townsend, G. (2014). Epigenetics: a new frontier in dentistry. Australian dental journal, 59(s1), 23-33.

183.Wong, G. K. Y., \& Chiu, A. T. (2010). Gene therapy, gene targeting and induced pluripotent stem cells: applications in monogenic disease treatment. Biotechnology advances, 28(6), 715-724.

184.Xie, N., \& Tang, B. (2016). The Application of Human iPSCs in Neurological Diseases: From Bench to Bedside. Stem Cells Int, 2016, 6484713. doi: 10.1155/2016/6484713

185. Yamada, Y. (2006). Genetic Disorders of the Indian Subcontinent. Journal of medical genetics, 43(3), 288.

186. Yazdi, F. T., Clee, S. M., \& Meyre, D. (2015). Obesity genetics in mouse and human: back and forth, and back again. PeerJ, 3, e856.

187. Yoo, H. W. (2010). Genetic testing in clinical pediatric practice. Korean Journal of Pediatrics, 53(3), 273-285.

188.Zeitlin, L., Rauch, F., Travers, R., Munns, C., \& Glorieux, F. H. (2006). The effect of cyclical intravenous pamidronate in children and adolescents with osteogenesis imperfecta type V. Bone, 38(1), 13-20.

189.Zemanick, E. T., Harris, J. K., Conway, S., Konstan, M. W., Marshall, B., Quittner, A. L., Accurso, F. J. (2010). Measuring and improving respiratory outcomes in cystic fibrosis lung disease: opportunities and challenges to therapy. Journal of Cystic Fibrosis, 9(1), 1-16. 